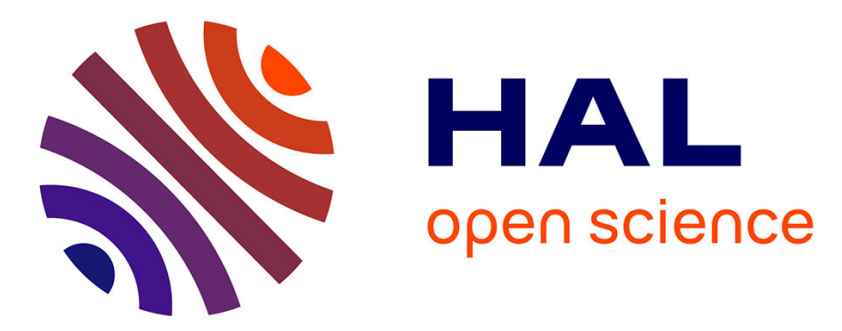

\title{
Interbank network characteristics, monetary policy "News" and sensitivity of bank stock returns
}

\author{
Aref Mahdavi Ardekani, Isabelle Distinguin, Amine Tarazi
}

\section{To cite this version:}

Aref Mahdavi Ardekani, Isabelle Distinguin, Amine Tarazi. Interbank network characteristics, monetary policy "News" and sensitivity of bank stock returns. 2019. hal-02384533

\section{HAL Id: hal-02384533 \\ https://hal-unilim.archives-ouvertes.fr/hal-02384533}

Preprint submitted on 28 Nov 2019

HAL is a multi-disciplinary open access archive for the deposit and dissemination of scientific research documents, whether they are published or not. The documents may come from teaching and research institutions in France or abroad, or from public or private research centers.
L'archive ouverte pluridisciplinaire HAL, est destinée au dépôt et à la diffusion de documents scientifiques de niveau recherche, publiés ou non, émanant des établissements d'enseignement et de recherche français ou étrangers, des laboratoires publics ou privés. 


\title{
Interbank network characteristics, monetary policy "News" and sensitivity of bank stock returns
}

\author{
Aref Mahdavi Ardekani ${ }^{1, *}$, Isabelle Distinguin ${ }^{1}$, Amine Tarazi ${ }^{1,2}$ \\ ${ }^{1}$ Université de Limoges, LAPE, 5 rue Félix Eboué, 87031 Limoges, France \\ ${ }^{2}$ Institut Universitaire de France (IUF), 1 rue Descartes, 75231 Paris Cedex 05, France
}

This draft: October 1, 2019

\begin{abstract}
This paper investigates whether interbank network topology influences the impact of monetary policy announcements on bank cumulative abnormal returns (CAR's). Although recent studies have emphasized the channels of non-conventional monetary policy actions and the sensitivity of bank stock prices to "News", how such reaction could be influenced by the shape of bank networks remains an open issue. We look at how banks' interconnectedness within interbank loan and deposit networks affects investors' expectations of future bank performance in response to monetary policy "News". Our sample consists of commercial, investment, real estate and mortgage banks in 10 Euro-zone countries. Our results show that the stock prices of banks with stronger local network positions are less sensitive to monetary policy announcements while those of banks with stronger system-wide positions are more sensitive to them.
\end{abstract}

Keywords: Interbank network topology, Monetary policy, bank's stock reaction, event study

JEL Classification : E52, E58, G14, G21, L14

\footnotetext{
${ }^{*}$ Corresponding author.

Email Address: aref.mahdavi@unilim.fr (A.M. Ardekani), isabelle.distinguin@unilim.fr (I. Distinguin), amine.tarazi@unilim.fr (A. Tarazi).
} 


\title{
Interbank network characteristics, monetary policy "News" and sensitivity of bank stock returns
}

This draft: October 1, 2019

\begin{abstract}
This paper investigates whether interbank network topology influences the impact of monetary policy announcements on bank cumulative abnormal returns (CAR's). Although recent studies have emphasized the channels of non-conventional monetary policy actions and the sensitivity of bank stock prices to "News", how such reaction could be influenced by the shape of bank networks remains an open issue. We look at how banks' interconnectedness within interbank loan and deposit networks affects investors' expectations of future bank performance in response to monetary policy "News". Our sample consists of commercial, investment, real estate and mortgage banks in 10 Euro-zone countries. Our results show that the stock prices of banks with stronger local network positions are less sensitive to monetary policy announcements while those of banks with stronger system-wide positions are more sensitive to them.
\end{abstract}

Keywords: Interbank network topology, Monetary policy, bank’s stock reaction, event study JEL Classification : E52, E58, G14, G21, L14 


\section{Introduction}

The interbank market is a crucial player in monetary policy transmission (Vari 2019; Freixas 2008). Consequently, a key objective of monetary policy is to ensure the smooth functioning of such a market. The increasing degree of interconnectedness among banks and complexity of interbank networks in recent decades enable efficient risk management and risk transfer but are also a potential source of contagion and systemic risk. Hence, analyzing the mechanisms of such interconnectedness in the interbank market is important to understand how turmoil influences the transmission of monetary policy.

Identifying the strategic interbank network players is crucial. Indeed, during the global financial crisis of 2007-2008, dominant interbank players did not actively fulfill their role as liquidity transmitters in the interbank market. On the one hand, dominant lenders (Hubs) hoarded liquidity as a result of widespread counterparty risks and fear about their solvency standards. This led to severe disruptions in the wholesale liquidity market (Berrospide 2013). On the other hand, dominant interbank borrowers (Authorities) that are heavily interconnected to those Hubs are subject to panic, which in the worst scenario may lead to widespread contagion. Therefore, the global financial crisis and the European sovereign debt crisis led to vast monetary easing policies around the globe and to the introduction of non-standard monetary policy measures called unconventional monetary policies to reduce tensions in the interbank market. Recent studies have highlighted the extensive amount of liquidity provided by the central banks of advanced countries to lower interest rates and affect the lending conditions of financial institutions (FIs) (Brana et al. 2018; Hofmann 2014; Keating et al. 2018; Wang 2019). Besides, central banks bought mortgagebacked securities, private sector debts, governmental bonds and followed other types of asset purchase programs at a large scale.

Such policies, which aim to support economic recovery, not only have an influence on liquidity and credit conditions of FIs, but also on equity markets. The reaction of bank stock returns to monetary policy announcements provides information on the impact of monetary policies on bank performance and more generally on their effectiveness in regulating the economy (Yin et al., 2010). The conventional and unconventional monetary policies affect the investment decisions of stock traders by shifting market expectations on future central bank policy rates and other effective macroeconomic indicators. The volatility of bank stock prices acts as an indicator of investors' trust in the banking system and in monetary authorities during the implementation of such policies. 
Bank stock returns depend on economic factors and bank-specific characteristics and hence differently react to monetary policy announcements. Yin et al. (2013) examine how the reactions of banks' stock prices to changes in the Fed funds rate are associated with banks' specific characteristics. They find that large banks and banks that rely more on non-deposit funding are more sensitive to such monetary policy changes whereas banks with higher capital ratios are less responsive. Ricci (2015) investigates the determinants of cumulative abnormal returns derived from banks' specific characteristics during the announcement of monetary policy actions by the European central bank (ECB). Her results show that the stock returns of banks with higher capital and liquidity ratios and lower systemic risk are less sensitive to monetary policy changes. Banks perceived as less safe by investors are more sensitive to monetary policy decisions.

This study contributes to the literature by investigating how bank stock returns respond to monetary policy announcements depending on the bank's position in the interbank network. More precisely, we investigate whether the position and strength of a bank within the interbank network weaken or strengthen stock market reactions to expansionary and restrictive monetary policy announcements. Some studies have focused on the impact of monetary policy on the functioning of the interbank market. Fiordelisi et al. (2014) and Ait-sahalia et al. (2012) show that standard monetary policy announcements have an impact on risk premia on the interbank market. Szczerbowicz (2015) argues that interbank transactions enhance monitoring and refinement of financial information among counterparties and, to such an extent, the ECB implements unconventional monetary policies to ensure smooth functioning of the interbank market. In addition, banks differently interact with their counterparties on the interbank market depending on the type of monetary policy. Ehrmann \& Worms (2001) document that during expansionary monetary policies small banks tend to deposit short-term funds in large banks. However, during restrictive monetary policies, to extend new loans, small banks rely on the domestic interbank market to attract funds while large banks receive liquidity from abroad. Bianchi \& Bigio (2014) highlight the impact of monetary policies on banks' reserves and on the market volume of interbank loans. Following monetary policy implementation, banks target different reserve and liquidity ratios depending on their interaction with other banks in the interbank network. Moreover, Ehrmann (2003) shows that the degree of bank liquidity is a key factor determining its response to monetary policy via reducing or increasing its loans. Therefore, the extent to which access to 
interbank liquid funds is more or less easy is expected to influence the reaction of banks' stock prices to central bank announcements.

Our paper is also related to several studies that have used bank network topology statistics to draw an accurate picture of the whole system. Martinez-Jaramillo et al. (2014) and Rørdam \& Bech (2009) compare the topologies of interbank exposure networks in different countries as well as those of payment flows and draw different topological characteristics of both mentioned networks. Iori et al. (2008); Kuzubaş et al. (2014) and Soramäki et al. (2007) assess the network topology of payment systems in different countries and look into the efficiency of the interbank market and the contribution of each bank to system stability. Chinazzi et al. (2013) and Soramäki et al. (2007) show that small and large banks are more willing to interact with each other in the interbank network than banks of the same size. Also, Gabrieli \& Georg (2014) highlight the higher access of banks with strong network centrality to the interbank liquidity market. We use network topology statistics to capture the interconnectedness among banks in the interbank network. These statistics enable us to quantify how banks can more or less easily have access to wholesale liquid funds. We distinguish local from systemwide network topology. While local network position measures the immediate access of banks to the interbank funds, systemwide network position assesses the critical role that each bank plays in the whole interbank market. We argue that the perception of the riskiness of banks by investors and thus their sensitivity to monetary policy decisions should be influenced by their interbank network characteristics especially in crisis times.

To conduct our research question, we consider the reaction of European bank stock prices to monetary policy announcements (conventional and unconventional) by the ECB during both the global and European sovereign debt crises (2008-2012) by focusing on the role of interbank network topology in European countries. Our findings highlight that the sensitivity of bank stock prices to announcements of both expansionary and restrictive monetary policies are not only influenced by specific risk factors but also by banks' position in the interbank network. On the whole, our findings indicate that the stock prices of banks with stronger local network positions are less sensitive to monetary policy announcements indicating that the market values interbank borrowing diversification. However, those of banks with stronger system-wide positions are more sensitive to these announcements. Dominant interbank borrowers that are linked with dominant 
interbank lenders are presumably perceived as risky in times of crisis probably because of liquidity hoarding behaviors of dominant lenders and contagion risk.

The rest of the paper is laid out as follows. Section 2 describes the data, variables and methodology, while section 3 presents the results of our study. Section 4 concludes the paper.

\section{Sample and Methodology}

This section presents the sample and the methodology used for the event study as well as the subsequent regression analysis.

\subsection{Sample}

We examine monetary policy announcements (conventional and unconventional) by the European Central Bank in crisis period from 2008 to 2012. The information on these announcements are collected from the ECB official press releases.

We classify monetary policies in two categories: (a) expansionary measures and (b) restrictive and policy-inaction measures ${ }^{1}$. Expansionary measures include liquidity provision (LPPs) and asset purchase (APPs) programs, which are the ECB's unconventional monetary tools as well as interest rate cuts (IR_CUT) which refer to conventional monetary policy tools. In the asset purchase program, the ECB buys the undervalued banks' securities or securities that are highly volatile during crisis times. Excess liquidity provisions are implemented by the ECB when the normal liquidity measures are not properly working during a financial crisis and thereupon, the ECB offers additional liquidity tools such as long-term refinancing operations (LTROs) with longer maturities. A restrictive or policy-inaction measure is when the ECB decides to increase or leave the interest rate (IR_UNC_INC) unchanged.

To deal with overlapping events, we apply the following criteria:

First, according to Ricci (2015), when several events belonging to the same monetary policy classification are announced on the same day, we count them as a single event. For example, on 12/08/2011 the ECB announced conducting two long-term refinancing operations (LTROs)

\footnotetext{
${ }^{1}$ Consistent with Aït-Sahalia et al. (2012), we group restrictive and policy inaction measures together as restrictive measures were scarce during the financial crisis.
} 
with a maturity of 36 months and a reduction of the reserve ratio. All these events are treated as a single event in the liquidity provision program (LPP) category.

Second, to identify the main event, consistent with Ricci (2015), we consider the announcement of a change in monetary policy (both conventional and unconventional monetary policies) as the main event, dropping from the event study the announcements of policy-inaction decisions or decisions to continue with a measure previously defined: e.g., on 6/9/2012, the ECB announced the details on the implementation of the Outright Monetary Transactions (OMTs). It also announced the decision to leave unchanged the interest rate on the main refinancing operations (MROs), Marginal Lending Facilities (MLFs) and deposit facilities. Therefore, we consider the first event as the main event.

Third, when the ECB implemented unconventional monetary policy tools for the first time, we consider this as the main event. For example, on 8/10/2008, the ECB first announced its list of extraordinary liquidity measures to help combat the financial crisis by introducing the fixed-rate full-allotment (FRFA). It also decided to reduce the main refinancing rate by 50 basis points. In this case, we give more relevance to the unconventional monetary policy announcement. However, if it is not the first time that such an unconventional policy is implemented, we give more relevance to the conventional measure.

Fourth, with respect to the frequency of unconventional monetary policy announcements, we give more relevance to the less frequent ones with longer time-interval between each announcement. On 6/10/2011, the ECB announced the second covered bond purchase program (CBPP2) and also 12-months and 13-months LTROs. Because CBPP2 was announced more than two years after CBPP1 (7/5/2009), we consider it as the main event, dropping LTROs from the event study analysis (details on LTROs decisions were previously announced on 4/8/2011 and $9 / 6 / 2011)^{2}$.

Our final sample includes 72 announcements (conventional and unconventional) corresponding to 26 expansionary measures (6 interest rate cuts, 13 LPPs and 7 APPs programs) and 46 restrictive or policy-inaction measures.

Daily stock market data of listed European banks from EEA (European Economic Area) are collected from the Bloomberg database and to retrieve annual bank-specific factors, we use the

\footnotetext{
${ }^{2}$ The third and fourth criteria help identifying 5 single events. Running a robustness check without these events does not alter our conclusions.
} 
BankScope database. We omit savings, mutual and cooperative banks due to their specificities in terms of interbank relationships (Boss \& Elsinger, 2004; BIS, 2001; Worms, 2001). Our final sample only includes listed commercial, investment, and real estate banks. After eliminating banks for which BankScope does not report information on our variables of interest and after merging these datasets, our final sample of listed banks consists of 37 banks from 10 EEA countries. We have winsorized extreme bank year observations for our dependent and bank-level control variables (1\% lowest and highest values).

\section{[Insert Table 1]}

\subsection{Bank Network}

To construct our interbank exposure network, we first need to estimate the bilateral interbank transactions between each pair of entities in the interbank loan and deposit markets. Indeed, a main weakness when studying the interbank exposure network is the lack of access to the bilateral interbank transactions as banks are not required to report this to regulatory authorities in most of the European countries. The only available bank-level data is aggregate interbank loans and deposits for each bank. Therefore, to scrutinize network characteristics at the bank level, we need to estimate these bilateral relationships by applying mathematical algorithms. We use the minimum density algorithm introduced by Anand et al. (2015). A notable point of applying this method is its economic rationality: producing and maintaining extra interbank links is costly and should be minimized ${ }^{3}$. Anand et al. (2018) compare different network-reconstruction methods for 25 distinct financial markets and show that minimum density is the best method to preserve the structure of links. Because interbank transactions are between both listed and unlisted banks, we construct our interbank networks by including all available commercial, investment and real estate banks in the BankScope database in each country. Therefore, our network statistics capture connections of banks in our sample with all possible banks in their respective country. Following Craig and Von Peter (2010) and Anand et al. (2015), we thus obtain a self-contained network at the country level excluding cross-border linkages ${ }^{4}$. By comparing the generated self-contained network against a real-world network excluding cross-border linkages, Anand et al. (2015) show

\footnotetext{
${ }^{3}$ See Anand et al. (2015) for more details on interbank network simulation.

${ }^{4}$ Note that, with the crisis, a tendency for a "home bias" in interbank lending occurred (ECB, 2012). The global financial crisis led to a precipitous retrenchment in cross-border linkages in Europe amplified by the euro area sovereign debt crisis.
} 
that the minimum density approach is the best approach to preserve the network's structural features.

The first step to study banking network characteristics (topology) is to characterize its features. We thus define each bank as a node indexed by $i=1$ to $\mathrm{N}$. aij corresponds to the link that connects node $\mathrm{i}$ to $\mathrm{j}$. The interbank market is a directed network in nature. Thus, $\mathrm{a}_{\mathrm{ij}} \neq \mathrm{a}_{\mathrm{ji}}$ which means that if node $i$ has a link with node $j$, it is not necessary that node $j$ be linked with $i$. The path length of node $\mathrm{i}$ to $\mathrm{j}$ corresponds to the number of links from $\mathrm{i}$ to $\mathrm{j}$. It shows that not all the nodes connect to each other directly. However, there could be indirect links between two different nodes through others. The geodesic path is the shortest possible distance between two given nodes, $\mathrm{i}$ and $\mathrm{j}$. It is denoted by $\mathrm{g}_{\mathrm{ij}}$. Sometimes there is more than one geodesic path between a pair of nodes.

Figure-1 synthesizes the interbank network configuration of two selected European countries (France and Germany) in 2008. Each node represents a bank in the network and the links represent the lending-borrowing relationships. Highlighted large nodes represent banks in our sample.

\section{[Insert Figure 1]}

The network tools for capturing connectedness between the nodes can be divided into local and system-wide variables. Local network statistics quantify each bank's interconnectedness with its local neighbors. System-wide network statistics assess the interbank network interconnectedness based on each bank's position in the whole network. They provide a wider view of banks interconnectedness as they measure each bank's access to the interbank market compared with all existing banks in the network. They thus give information about the possible counterparty, contagion and systemic risks that would arise through this interconnectedness.

We consider In-degree as our local network measurement. In network science, it is the number of incoming links to each node. In our study, it corresponds to the number of banks that have deposits in bank i. Thus, it is a measure of the bank's ability to diversify its borrowing on the interbank market.

$D_{i}^{i n}=\sum_{j} a_{j i}$ 
Banks' lending-borrowing relationships play an important role in interest rate setting on the interbank market (Temizsoy, Iori, and Montes-Rojas 2015; Cocco, Gomes, and Martins 2009; Furfine 2001). Those relationships may in turn increase or reduce the stock price sensitivity of banks with strong local interconnectedness to the monetary policy announcements. On the one hand, because banks with strong local (In-Degree) positions are connected to a large number of immediate interbank lenders, they are expected to be sheltered from short-term impacts of monetary policy changes as they optimally diversify their interbank borrowing. Besides, those banks are more exposed to market discipline as they are monitored by a large number of counterparties. On the other hand, borrowing diversification may increase uncertainty as a result of higher asymmetry of information. Indeed, diversification lessens the relationship lending advantages of banks with few informed lenders (Temizsoy et al. 2015).

Our tool to capture system-wide network position is Authority that measures the importance of each bank's total number of interbank lenders (incoming links) relative to the other banks in the network but also considers the strength of its lenders based on their outgoing links. Therefore, banks with strong Authority are those that are connected to strong Hubs (dominant lenders) in the network. Authority is calculated based on the HITS algorithm (Kleinberg 1999). Kleinberg algorithm includes an iterative procedure for computing the Authority centrality of each node. The two network variables (In-degree and Authority) are calculated based on the software developed by Bastian and Heymann (2009).

As documented by León et al. (2018), during crisis times, dominant interbank lenders tend to hoard liquidity as a result of widespread counterparty risks and fear about their solvency standards. Therefore, dominant borrowers with strong linkages with those banks may be exposed to severe liquidity risk. This might cause higher stock price reactions to the monetary policy announcements. However, dominant interbank borrowers might be less sensitive to the monetary policy announcements if equity investors expect that those dominant borrowers will be bailed out by the lender of last resort in case of default to avoid contagion and systemic risk (Temizsoy et al., 2017).

Figure-2 represents banks in our sample based on their local and systemwide interconnectedness in 2008. As visualized in this figure, there is a positive correlation between InDegree and Authority for the banks in our sample. However, few banks are characterized by strong 
Authority and weak In-Degree. Those banks are considered as a source of contagion and systemic risk as they are more connected to the strongly interconnected lenders, have a less diversified borrowing structure in the interbank market and are less exposed to market discipline. This is consistent with Temizsoy et al. (2017) findings on the network visualization analysis of Euro area and US e-MID market.

\section{[Insert Figure 2]}

\subsection{Event study}

We measure the reaction of a bank's stock price to monetary policy announcements by the ECB by employing an event-study approach.

Following Fiordelisi et al. (2014) and Ricci (2015), cumulative abnormal returns (CARs) are estimated using the standard market model over a 252 days estimation period ending 20 days prior to the announcement date. These estimations include countries' main market indexes. Consistent with Aït-sahalia et al. (2012) and Ricci (2015), we consider a one-day event window $(0,0)$, a two-day event window $(0,1)$, a three-day event window $(-1,1)$ and a five-day event window (-1, 3). Subsequent to estimating CARs, we apply parametric Boehmer et al. (1991) and Kolari and Pynnönen (2010) test statistics to examine whether the reaction of bank stock prices to those events is significantly different from zero.

Standard cross-sectional Boehmer et al. (1991) test takes into account serial correlation of ARs and event induced volatility. The standardized residual is calculated as:

$$
\mathrm{SR}_{\mathrm{i}}=\frac{\operatorname{CAR}_{i}\left(t_{1}, t_{2}\right)}{\widehat{\sigma}_{\varepsilon_{i}} \sqrt{T_{S}+\frac{T_{S}^{2}}{T}+\frac{\sum_{t=t_{1}}^{t_{2}}\left(R_{m t^{-}} T_{S}(\overline{R m})^{2}\right.}{\sum_{t=1}^{T}\left(R_{m t^{-}}\left(\overline{R_{m}}\right)^{2}\right.}}}
$$

Where $C A R_{i}\left(t_{1}, t_{2}\right)$ is the cumulative abnormal return over the event window, $\hat{\sigma}_{\varepsilon_{i}}$ is the estimated standard deviation of abnormal returns during the estimation period, $\mathrm{T}_{\mathrm{s}}$ is the number of days in the event window, $\mathrm{R}_{\mathrm{mt}}$ is the market return on day $\mathrm{t}, \overline{R_{m}}$ is the average market return during the estimation period and $\mathrm{T}$ is the number of days in the estimation period. Then, the Z-statistics for testing $\mathrm{H}_{0}$ : CARs $=0$ are given by: 


$$
\mathrm{Z}_{\mathrm{Boehmer}}=\frac{\frac{1}{N} \sum_{i=1}^{N} S R_{i}}{\sqrt{\frac{1}{N(N-1)} \sum_{i=1}^{N}\left(S R_{i}-\sum_{i=1}^{N} \frac{S R_{i}}{N}\right)^{2}}}
$$

To consider the cross-correlation of ARs, we use the Kolari and Pynnönen (2010) test statistic. It adjusts the average ARs' variance in the event window using the residual correlation in the estimation window. The Z-statistics for testing $\mathrm{H}_{0}$ : CARs $=0$ are given by:

$$
Z_{\text {Kolari \& Pynnonen }}=\frac{\frac{1}{N} \sum_{i=1}^{N} S R_{i}}{\sqrt{\frac{1}{N(N-1)} \sum_{i=1}^{N}\left(S R_{i}-\sum_{i=1}^{N} \frac{S R_{i}}{N}\right)^{2}}} * \sqrt{\frac{1-\bar{r}}{1+(N-1) \bar{r}}}
$$

Where $\bar{r}$ is the mean of the sample cross-correlations of the estimation period residuals and $\mathrm{N}$ is the number of observations in the respective sample.

Given the important role of interbank market in reallocation of liquidity between banks and transmission of monetary policies, it is important to investigate the reaction of bank stock returns to monetary policy announcements depending on their strong or weak positions in the interbank network. For this purpose, we distinguish banks with extremely strong or weak network position in the interbank market by computing the $25^{\text {th }}$ and the $75^{\text {th }}$ percentiles of our local network variable (In-Degree) and our system-wide network variable (Authority). We then test the significance of the reaction of banks' stock prices to monetary policy announcements on these sub-samples.

\subsection{Regression model}

To investigate the determinants of banks' stock prices reaction, we run two OLS models. The first model considers the determinants of the absolute value of CARs on the ECB expansionary measure announcements and the second model on the ECB restrictive measure announcements.

$\operatorname{CAR}_{i, j}^{\text {Expansionary }}=\alpha_{1}+\alpha_{2}$ In-Degree $_{\mathrm{i}, \mathrm{t}-1}+\alpha_{3}$ Authority $_{\mathrm{i}, \mathrm{t}-1}+\alpha_{4}$ In-Degree $_{\mathrm{i}, \mathrm{t}-1} *$ AssetPurchase $_{\mathrm{j}}+\alpha_{5}$ Authority $_{\mathrm{i}, \mathrm{t}-1} *$

AssetPurchase $_{\mathrm{j}}+\alpha_{6}$ In-Degree $_{\mathrm{i}, \mathrm{t}-1} * \mathrm{IR}_{-} \mathrm{CUT}_{\mathrm{j}}+\alpha_{7}$ Authority $_{\mathrm{i}, \mathrm{t}-1} * \mathrm{IR}_{-} \mathrm{CUT}_{\mathrm{j}}+\alpha_{8} \mathrm{BF}_{\mathrm{i}, \mathrm{t}-1}+\alpha_{9}$ ILD $_{z, \mathrm{t}}+\alpha_{10}$ Sovereign_Crisis $t+\alpha_{11}$ Global_Crisis $t+\alpha_{12}$ AssetPurchase $_{j}+\alpha_{13}$ IR_CUT $_{j}+e_{i, t}$

CAR Restrictive $_{i, j}^{\text {Re }} \alpha_{1}++\alpha_{2}$ In-Degree $\mathrm{i,t-1}+\alpha_{3}$ Authority $_{\mathrm{i}, \mathrm{t}-1}+\alpha_{4} \mathrm{BF}_{\mathrm{i}, \mathrm{t}-1}+\alpha_{5} \operatorname{ILD}_{\mathrm{z}, \mathrm{t}}+\alpha_{6}$ Sovereign_Crisis $\mathrm{t}_{\mathrm{t}}+\alpha_{7}$ Global_Crisis ${ }_{t}+e_{i, t}$ 
Where $C A R_{i, j}$ stands for the absolute value of cumulative abnormal returns on the $(-1,3)$ event window ${ }^{5}$ for the $\mathrm{i}$-th bank to the $\mathrm{j}$-th announcement. $\alpha_{1}$ is a constant, BF is a vector of bank factors for bank i in year t-1, In-Degree and Authority are our network variables, and ILD is Interbank Loans-Density of country $\mathrm{z}$ in year $\mathrm{t}$ defined as the ratio of aggregate interbank loans to aggregate bank assets at the sample level within each country. We use the one year lagged value of our network variables as well as our bank-level controls according to Huang, Schwienbacher, and Zhao (2012) to avoid bias in our estimations due to potential endogeneity issues. Sovereign_Crisis is an European sovereign crisis dummy variable that takes the value of one for the 2010-2011 period and Global_Crisis takes the value of one for the year 2008. AssetPurchase is an asset purchase program dummy that takes the value of one for the events involved in this program. The IR_CUT dummy refers to the ECB monetary policy decisions to cut interest rates.

Bank level control variables (BF) include the ratio of net loans to deposit and short-term funds $\left(N L \_D S T F\right)$, the Interbank ratio (IntrBR), a bank size variable (Bank_Size), the Z-Score, the cost to income ratio (Cost_Inc), Return on Average Assets (ROAA) and Equity to total assets $\left(E q \_T A\right)$.

Ricci (2015) and Yin \& Yang (2013) show that liquid banks are less sensitive to monetary policy announcements. We consider $N L \_D S T F$ and InterBR as bank liquidity measurements. $N L \_D S T F$ considers the amounts of deposits and short-term debt employed by banks to fund their loan portfolio. A lower ratio indicates higher bank liquidity. We expect a positive relationship between this ratio and $C A R$ as illiquid banks (banks with a higher ratio) are perceived as riskier by investors. Interbank ratio (IntrBR) is the ratio of "Due from banks" to "Loans from banks". Banks in a lending position on the interbank market are less likely to experience liquidity tensions. In general, and consistently with our hypotheses, we assume that banks with high interbank ratios are less sensitive to monetary policy announcements as they benefit more from interacting with their interbank competitors than from central bank intervention.

Castrén, Fitzpatrick, \& Sydow (2006) show that the reaction of banks' stock returns to various events depends on the firm's size. Larger banks are more sensitive to banking events than

\footnotetext{
${ }^{5}$ For robustness, we run our regressions on the CARs estimated on 1-day $(0,0)$ 2-day $(0,1)$ and 3-day $(-1,1)$ event windows (see 4.1).
} 
small ones. To control for bank size effects, we consider the logarithm of bank total assets (Bank_Size). We expect a positive relationship between bank size and CAR.

Yin \& Yang (2013) highlight that banks with lower default risk (higher Z-Score) are less sensitive to monetary policy changes. We also introduce the Z-Score, which is an indicator of distance to bankruptcy. The higher this ratio is, the lower the probability of default. Z-score in this study is calculated as:

Zscore $=\frac{\text { ROAmma3 }+\left(\frac{\text { Equity }}{T A}\right) m m a 3}{\text { ROAsdma3 }}$

where ROAmma3 is the 3-year rolling window average return on assets defined as the ratio of net income to average total assets, (Equity/TA)mma3 represents the 3-year rolling window average of equity to total assets and ROAsdma3 stands for the 3-year rolling window standard deviation of the return on assets. All the ratios are in percentages. The expected relationship between $Z$-score and CARs is negative. By reducing its default probability (higher Z-Score), the bank is considered as less risky by investors.

We include the return on average assets $(R O A A)$ as a measure of the bank's overall profitability. We expect a negative relationship between CARs and ROAA since the stock price of more profitable banks might be less influenced by monetary policy announcements.

We consider the cost to income ratio (Cost-income) as a proxy of bank cost efficiency. Consistent with Ricci (2015), we expect a positive coefficient for Cost-income as banks with higher cost efficiency (lower value of Cost-income) on average are less sensitive to ECB unconventional monetary policies.

Madura and Schnusenberg (2000), Ricci (2015) and Yin et al. (2013) find that banks with higher capital ratios are less sensitive to monetary policy changes. Increasing bank capital ratios means reducing leverage and consequently lowering liquidity risk. We consider Equity to total asset ratio $\left(E q \_T A\right)$ as a proxy of bank capitalization. We expect banks with a higher capital ratio to be less sensitive to monetary policy announcements.

As indicated above, we also introduce a variable at the country level (ILD) to control for country effects. We expect a positive sign for the coefficient of this variable since banks in a country with high interbank Loans-Density should be more affected by monetary policy changes. 
The correlation matrix and descriptive statistics are presented in Table- 2 and Table- 3 respectively.

The correlation coefficients between our independent variables are low except between bank size as measured by the natural logarithm of total assets (Bank-Size) and one of our network measures (In-Degree). To check whether such correlation affects our results, we have performed two robustness tests. We have replaced Bank-Size by a size dummy variable which is not correlated with In-Degree. We have also orthogonalized the logarithm of total assets with our network measure (In-Degree) and introduced our network variable and the residual component of bank size. All the specifications yield qualitatively similar results (see 4.3.). Thus, all the results presented below are those obtained with Bank-Size and In-Degree introduced simultaneously ${ }^{6}$.

\section{[Insert Table 2]}

[Insert Table 3]

\section{Results}

\subsection{Event study}

The results of our event study for EEA countries are presented in Table 4. Conventional monetary policies are classified into the ECB regular interest rate decisions to cut (IR_CUT), increase or leave unchanged the interest rate (IR_UNC_INC) and unconventional measures include liquidity provision (LPP) and asset purchase programs (APP). The main market index for each country is chosen to estimate the market model. Overall, when considering the full sample irrespective of banks' network characteristics (Panel A) we do not find significant reactions of bank stock returns to announcements of either expansionary or restrictive monetary policies.

[Insert Table 4]

\footnotetext{
${ }^{6}$ We also perform multicollinearity checks among all variables by running a VIF test. The results of the VIF test in Table 5 and Table 6 indicate low multicollinearity. In addition, Table A1 reports VIF test results for all our independent and control variables in equation 6. The VIF statistics range from 1.13 to 2.20 indicating low multicollinearity among the variables.
} 
However, by considering banks' network positions (Panels B and C), we find that bank stock returns significantly and differently react depending on the strength of their local and systemwide position.

While stock returns do not react to conventional expansionary monetary policy announcements for banks with either extremely weak or extremely strong network positions, they react positively to unconventional monetary policy announcements for banks with extremely strong local network positions and negatively for banks with extremely strong system-wide network positions.

More precisely, we find that stock returns of banks with a strong local network position positively react to the announcements of LPPs, while banks with a strong systemwide network position negatively react to these announcements. The announcements of LPP can be interpreted by the market as a signal of higher liquidity risk in the banking system or be perceived positively as it increases the supply of liquidity on the interbank market. On the one hand, banks with strong Authority are considered as a significant source of contagion and systemic risk. Therefore, they are possibly more affected by the negative signal transmitted by the LPPs announcements. This could lead to the negative reaction. On the other hand, LPPs might be perceived positively by investors of banks with strong In-Degree as, due to their more diversified borrowing structure in the interbank market, these announcements might only signal better bank liquidity positions.

Considering Asset Purchase programs, only CARs of banks with strong In-Degree positively react to these announcements. By purchasing risky securities and covered bonds, the ECB assumes the default risk and liquidity risk of these assets for Euro-zone members, which implies lower risk-taking by investors. This is perceived as good news by investors of banks with strong local interconnectedness as those policies might reinforce bank liquidity positions. These announcements might lead to contrasted reactions for banks with a strong system-wide position as it also signals liquidity problems. Our findings also highlight that stock returns of banks with weak network positions do not react to unconventional monetary policy announcements. Unconventional monetary policies are implemented to reduce tensions in the interbank network. Banks with weak local and system-wide positions are not active players in the interbank network, which might explain why there is no significant reaction to those announcements. 
The results for policy-inaction or restrictive monetary policies (IR_UNC_INC) show that stock returns of banks with weak In-Degree and Authority in the interbank network negatively react to these announcements. Bernanke and Blinder (1988) argue that deposits fall during restrictive monetary policy regimes and banks may look for other source of liabilities to fund their loan portfolios. Because of the limited access to the interbank market, weakly interconnected banks may experience higher borrowing cost, which could possibly explain these negative reactions.

\subsection{Network variables and the impact of monetary policy announcements on the absolute value of CARs}

So far, we find that banks with distinct interbank network positions differently react to monetary policy announcements. To go deeper in our empirical investigation, we examine how the interbank network topology influences the extent of bank stock price reaction to monetary policy announcements.

To conduct our OLS model, we select the interest rate cut, liquidity provision programs and asset purchases programs announced by the ECB as expansionary monetary policies and increased or unchanged interest rates as restrictive and neutral monetary policies from 2008 to 2012. We run the regression on the absolute value of CARs of the 37 European banks in our sample to determine the impact of banks' network measures on the sensitivity of their stock prices to the ECB's announcements.

Table 5 reports the results of our regressions explaining the absolute value of EEA listed banks' CARs in response to ECB expansionary and restrictive monetary policy announcements. We find contradictory impacts of local and system-wide network measures on the absolute value of CARs during announcements of both conventional and unconventional monetary policies. While In-Degree has a negative impact on the absolute value of CARs, Authority is positively related to banks' absolute CARs. Our findings highlight that banks with stronger local interconnectedness are perceived as less risky by investors as they have stronger capacity to diversify their borrowing through the interbank market and are more exposed to the market discipline in the interbank network. Consequently, they are less affected by these ECB monetary programs. Banks with strong system-wide interconnectedness could obtain cheaper liquidity through the interbank market because of their wider access to the interbank network during normal times. However, they possibly lose their system-wide network advantages during stress times as 
they are connected to the dominant interbank lenders which are characterized by a high probability of hoarding liquidity during turmoil. Accordingly, they are perceived risky by market investors, which makes their stock price react more to the ECB monetary policy announcements.

\section{[Insert Table 5]}

Considering control variables, the significantly positive coefficient of the logarithm of total assets (Bank_Size) shows that larger banks are more sensitive to the ECB monetary policy announcements. For liquidity, the significantly negative coefficient of $N L \_D S T F$ indicates that less liquid banks are less sensitive to the ECB restrictive monetary policy changes, the significantly positive coefficients of IntrBR suggests that banks with a net lending position in the interbank market are more sensitive to monetary policy announcements.

The Z-score has a negative and statistically significant coefficient for both expansionary

and restrictive measures. Banks with lower default risk are less sensitive to the ECB monetary policy announcements.

The interbank Loans-Density variable (ILD) is positively and significantly related to the absolute CARs, which implies that banks in a country with higher share of interbank loans to banks' total assets are more sensitive to both expansionary and restrictive monetary policy announcements compared to banks in other countries.

To sum-up, we find that a stronger local network position decreases the sensitivity of bank stock prices to monetary policy announcements, while a stronger system-wide network position is associated with stronger reactions to these announcements. Thus, our results indicate that interbank borrowing diversification and market discipline are valued by the market and lead to less reactions to monetary policy announcements. Strong system-wide interconnectedness is perceived as risky in times of crisis and leads to higher market reactions following monetary policy announcements.

\subsection{Does diversification matter for dominant borrowers?}

Given that a diversified borrowing structure in the interbank market is valued by investors and results in less reaction to monetary policy announcements, an important question is whether it can mitigate the negative effect of being a dominant borrower. 
To address this issue, we introduce a dummy variable (In-Degree 75 ) that takes the value of one if In-Degree is greater than or equal to the $75^{\text {th }}$ percentile value and interact it with the systemwide network position (Authority).

As shown in Table 6, the Authority of banks with high In-Degree does not have an impact on the absolute value of CARs during announcements of expansionary monetary policies. Concerning restrictive monetary policy announcements, while Authority has a positive impact on the absolute value of CARs, its positive effect is lower for banks with high In-Degree. Whereas equity investors might believe that banks with stronger systemwide connections are more exposed to liquidity risk and contagion, these types of interconnectedness might be perceived less risky when banks are backed by optimally diversified lenders in the interbank network ${ }^{7}$.

\section{Robustness checks}

To check the robustness of our results, we conduct several sensitivity analyses.

\subsection{Shorter event windows}

As a robustness check, we run our regressions on the absolute value of CARs estimated on 1-day $(0,0), 2$-day $(0,1)$ and 3 -day $(-1,1)$ event windows. When considering expansionary measures (Table A2), results for 3-day event window remain unchanged. However, by reducing the event window to 2-day and 1-day, network variables either local or system-wide lose their significance in explaining the absolute value of CARs for APPs. Results obtained when considering the announcements of restrictive monetary policies are unaltered for all event windows (Table A3).

\subsection{Alternative network measures}

We perform a robustness check by considering two alternative measures of local and system-wide network characteristics. We choose Degree as a representative of bank local position and Closeness Centrality as a representative of bank system-wide position in the interbank network.

\footnotetext{
${ }^{7}$ We also ran regressions using an alternative definition for high diversification, In-Degree50, that takes the value of one if In-Degree is greater than or equal to the median value. We find similar results: the impact of Authority is lower for high values of In-Degree (see 4.4).
} 
Degree, in network science, is the total number of incoming and outgoing links to and from each node. In our study, it corresponds to the number of banks that have deposits in or a loan from bank $i$. Thus, it is a measure of the bank's 'liability \& asset sides' diversification.

$D_{j}=\sum_{j} a_{j i}+\sum_{j} a_{i j}$

Closeness centrality measures how close each bank is to the other banks in the network based on distance ${ }^{8}$. So, banks with high closeness ratios could have more access to the interbank market as they can lend or borrow more directly to and from other banks. They can facilitate the spread of liquidity as well as the spread of shocks. It is calculated by measuring the reverse distance of each bank to all other banks:

$C_{i}=\frac{1}{\sum_{j} \Sigma_{j=1}^{g} d_{i j}}$

In which $d_{i j}$ is the shortest distance between banks $\mathrm{i}$ and $\mathrm{j}$.

Table A4 represents our results. Our main findings for both expansionary and restrictive monetary policies remain unchanged.

\subsection{Orthogonalization of bank size and the network variable and Size Dummy variable}

The logarithm of bank total assets (Bank-Size) and In-Degree are correlated at $61 \%$. To ensure that this correlation does not affect our results, we perform a robustness test by orthogonalizing the logarithm of total assets with our network measure (In-Degree). We then introduce our network variable and the residual component of bank size. Alternatively, we replace Bank_Size with a dummy variable (Size_Dummy) that takes the value of one for small banks (banks with total assets less than one billion Euro) and zero otherwise. As shown in Table A5, our main results remain unchanged.

\subsection{Alternative definition for high diversification of borrowing structure}

When looking at whether borrowing structure diversification can mitigate the negative effect of being a dominant borrower, we consider an alternative definition for high diversification, In-

\footnotetext{
${ }^{8}$ Distance is measured based on the number of intermediate banks between two arbitrary banks.
} 
Degree50, that takes the value of one if In-Degree is greater than or equal to the median value. We find similar results: the impact of Authority is lower for high values of In-Degree (Table A6).

\section{Conclusion}

This study investigates the channels of monetary policy transmission on European banks by analyzing the effects of ECB actions. Specifically, we investigate the reaction of bank stock prices to monetary policy announcements by considering banks' network position on the interbank market. Our findings show that banks' stock price reaction to monetary policy announcements strongly depends on their network characteristics. A larger number of immediate local lenders decreases the sensitivity of bank stock prices to monetary policy announcements, while a stronger system-wide network borrower position is associated with a stronger reaction to these announcements. Indeed, bank network topology captures the extent to which banks have more or less easy access to interbank liquidity as well as counterparty risk. Our findings shed light on the importance of a diversified borrowing structure in the interbank market as it is valued by the market and results in less reactions to monetary policy announcements. In addition, we show that banks with a strong system-wide network position are presumably perceived riskier by market participants because of their fragile network position in the interbank market during crisis times: they are connected to dominant interbank lenders that can hoard liquidity during financial turmoil. Therefore, our findings indicate that regulatory authorities should require such banks to hold more liquidity to reduce their dependency to non-standard monetary policies. 


\section{References:}

Aït-sahalia, Yacine, Jochen Andritzky, Andreas Jobst, Sylwia Nowak, and Natalia Tamirisa. 2012. "Market Response to Policy Initiatives during the Global Fi Nancial Crisis." Journal of International Economics 87 (1): 162-77. https://doi.org/10.1016/j.jinteco.2011.12.001.

Aït-Sahalia, Yacine, Jochen Andritzky, Andreas Jobst, Sylwia Nowak, and Natalia Tamirisa. 2012. "Market Response to Policy Initiatives during the Global Financial Crisis." Journal of International Economics 87 (1): 162-77. https://doi.org/10.1016/j.jinteco.2011.12.001.

Anand, Kartik, Ben Craig, and Goetz von Peter. 2015. "Filling in the Blanks: Network Structure and Interbank Contagion." Quantitative Finance 15 (4): 625-36. https://doi.org/10.1080/14697688.2014.968195.

Anand, Kartik, Iman van Lelyveld, Ádám Banai, Soeren Friedrich, Rodney Garratt, Grzegorz Hałaj, Jose Fique, et al. 2018. "The Missing Links: A Global Study on Uncovering Financial Network Structures from Partial Data." Journal of Financial Stability 35: 107-19. https://doi.org/10.1016/j.jfs.2017.05.012.

Bernanke, Ben, and Alan Blinder. 1988. "Credit, Money, and Aggregate Demand." American Economic Review, no. 78. https://doi.org/10.3386/w2534.

Berrospide, Jose M. 2013. "Bank Liquidity Hoarding and the Financial Crisis: An Empirical Evaluation.” BIS Working Papers, no. April. https://doi.org/10.2139/ssrn.2207754.

Bianchi, Javier, and Saki Bigio. 2014. "Banks, Liquidity Management and Monetary Policy." NBER Working Paper Series, no. July: 1-64. https://doi.org/10.3386/w20490.

BIS. 2001. Marrying the Macro- and Micro-Prudential Dimensions of Financial Stability. Working Paper Series. https://doi.org/10.2139/ssrn.1165494.

Boehmer, Ekkehart, Jim Masumeci, and Annette B. Poulsen. 1991. "Event-Study Methodology under Conditions of Event-Induced Variance." Journal of Financial Economics. https://doi.org/10.1016/0304-405X(91)90032-F.

Boss, Michael, and Helmut Elsinger. 2004. "An Empirical Analysis of the Network Structure of the Austrian Interbank Market." Financial Stability Report, 77-87.

Brana, Sophie, Alexandra Campmas, and Ion Lapteacru. 2018. "(Un)Conventional Monetary Policy and Bank Risk-Taking: A Nonlinear Relationship.” Economic Modelling, no. July: 118. https://doi.org/10.1016/j.econmod.2018.07.005.

Castrén, Olli, Trevor Fitzpatrick, and Matthias Sydow. 2006. "What Drives EU Banks Stock Returns? Bank-Level Evidence Using the Dynamic Dividend-Discount Model." Working Paper Series, no. 677. http://ideas.repec.org/p/ecb/ecbwps/20060677.html.

Chinazzi, Matteo, Giorgio Fagiolo, Javier A. Reyes, and Stefano Schiavo. 2013. "Post-Mortem Examination of the International Financial Network." Journal of Economic Dynamics and Control 37 (8): 1692-1713. https://doi.org/10.1016/j.jedc.2013.01.010.

Cocco, João F., Francisco J. Gomes, and Nuno C. Martins. 2009. "Lending Relationships in the Interbank Market." Journal of Financial Intermediation 18 (1): 24-48. 
https://doi.org/10.1016/j.jfi.2008.06.003.

Craig, Ben, and Goetz Von Peter. 2010. "Interbank Tiering and Money Center Banks." BIS Working Papers, no. 322. http://www.bis.org/publ/work322.pdf.

ECB. 2012. "Changes in Bank Financing Patterns.” ECB Working Paper Series.

Ehrmann, M. 2003. "The Effects of Monetary Policy in the Euro Area." Oxford Review of Economic Policy 19 (1): 58-72. https://doi.org/10.1093/oxrep/19.1.58.

Ehrmann, MICHAEL, and ANDREAS Worms. 2001. "Interbank Lending and Monetary Policy Transmission: Evidence for Germany." ECB Working Paper Series.

Fiordelisi, Franco, Giuseppe Galloppo, and Ornella Ricci. 2014. "The Effect of Monetary Policy Interventions on Interbank Markets, Equity Indices and G-SIFIs during Financial Crisis." Journal of Financial Stability 11 (1): 49-61. https://doi.org/10.1016/j.jfs.2013.12.002.

Freixas, Xavier. 2008. "The Role of Interbank Markets in Monetary Policy: A Model with Rationing." Journal of Money, Credit and Banking 40 (6).

Furfine, Craig. 2001. "Banks as Monitors of Other Banks: Evidence from the Overnight Federal Funds Market." Journal of Business 74: 33-57. https://doi.org/10.1086/209662.

Gabrieli, Silvia, and Co-Pierre Georg. 2014. "A Network View on Interbank Market Freezes." Banque de France Working Paper, no. 531.

Hofmann, Boris. 2014. "The Effectiveness of Unconventional Monetary Policy at the Zero Lower Bound : A Cross-Country Analysis.” Journal of Money, Credit and Banking 46 (4).

Huang, Weihua, Armin Schwienbacher, and Shan Zhao. 2012. "When Bank Loans Are Bad News: Evidence from Market Reactions to Loan Announcements under the Risk of Expropriation." Journal of International Financial Markets, Institutions and Money 22 (2): 233-52. https://doi.org/10.1016/j.intfin.2011.09.004.

Iori, G., De Masi G., O.V. Precup, G. Gabbi, and G. Caldarelli. 2008. "A Network Analysis of the Italian Overnight Money Market." Journal of Economic Dynamics and Control 32 (1): 25978. https://doi.org/10.1016/j.jedc.2007.01.032.

Keating, John W, Logan J Kelly, A L E E Smith, and Victor J Valcarcel. 2018. "A Model of Monetary Policy Shocks for Financial Crises and Normal Conditions." Journal of Money, Credit and Banking. https://doi.org/10.1111/jmcb.12522.

Kleinberg, Jon M. 1999. "Authoritative Sources in a Hyperlinked Environment." Journal of the ACM 46 (May 1997): 668-77. https://doi.org/10.1.1.120.3875.

Kolari, James W., and Seppo Pynnönen. 2010. "Event Study Testing with Cross-Sectional Correlation of Abnormal Returns." Review of Financial Studies 23 (11): 3996-4025. https://doi.org/10.1093/rfs/hhq072.

Kuzubaş, Tolga Umut, Inci Ömercikoğlu, and Burak Saltoğlu. 2014. "Network Centrality Measures and Systemic Risk: An Application to the Turkish Financial Crisis." Physica A: Statistical Mechanics and Its Applications 405: 203-15. https://doi.org/10.1016/j.physa.2014.03.006. 
León, Carlos, Clara Machado, and Miguel Sarmiento. 2018. "Identifying Central Bank Liquidity Super-Spreaders in Interbank Funds Networks." Journal of Financial Stability. https://doi.org/10.1016/j.jfs.2016.10.008.

M. Bastian, S. Heymann, M. Jacomy et al. 2009. "Gephi: An Open Source Software for Exploring and Manipulating Networks." Proceedings of International AAAI Conference on Web and Social Media, 361-362.

Madura, Jeff, and Oliver Schnusenberg. 2000. "Effect of Federal Reserve Policies on Bank Equity Returns." The Journal of Financial Research XXIII (4): 421-47. https://doi.org/10.1111/j.1475-6803.2000.tb00754.x.

Martinez-Jaramillo, Serafin, Biliana Alexandrova-Kabadjova, Bernardo Bravo-Benitez, and Juan Pablo Solórzano-Margain. 2014. "An Empirical Study of the Mexican Banking System's Network and Its Implications for Systemic Risk." Journal of Economic Dynamics and Control 40: 242-65. https://doi.org/10.1016/j.jedc.2014.01.009.

Quint, Dominic, and Pau Rabanal. 2017. "Should Unconventional Monetary Policies Become Conventional ?" IMF Working Paper, no. 85.

Ricci, Ornella. 2015. "The Impact of Monetary Policy Announcements on the Stock Price of Large European Banks during the Financial Crisis.” Journal of Banking and Finance 52: 245-55. https://doi.org/10.1016/j.jbankfin.2014.07.001.

Rørdam, Kirsten Bonde, and Morten L. Bech. 2009. "The Topology of Danish Interbank Money Flows." Banks and Bank Systems 4 (4): 48-65.

Soramäki, Kimmo, Morten L. Bech, Jeffrey Arnold, Robert J. Glass, and Walter E. Beyeler. 2007. "The Topology of Interbank Payment Flows." Physica A: Statistical Mechanics and Its Applications 379 (1): 317-33. https://doi.org/10.1016/j.physa.2006.11.093.

Szczerbowicz, Urszula. 2015. “The ECB Unconventional Monetary Policies: Have They Lowered Market Borrowing Costs for Banks and Governments?" International Journal of Central Banking 11 (4): 91-127.

Temizsoy, Asena, Giulia Iori, and Gabriel Montes-Rojas. 2015. "The Role of Bank Relationships in the Interbank Market." Journal of Economic Dynamics and Control 59 (14): 118-41. https://doi.org/10.1016/j.jedc.2015.07.008.

_ 2017. "Network Centrality and Funding Rates in the E-MID Interbank Market." Journal of Financial Stability 33 (June 2007): 346-65. https://doi.org/10.1016/j.jfs.2016.11.003.

Vari, Miklos. 2019. "Monetary Policy Transmission with Interbank Market Fragmentation." Journal of Money, Credit and Banking 00 (0). https://doi.org/10.1111/jmcb.12604.

Wang, Ling. 2019. "Measuring the Effects of Unconventional Monetary Policy on MBS Spreads: A Comparative Study." The North American Journal of Economics and Finance. https://doi.org/10.1016/j.najef.2019.03.020.

Worms, Andreas. 2001. "The Reaction of Bank Lending to Monetary Policy Measures in Germany." ECB Working Paper Series. 
Yin, Haiyan, and Jiawen Yang. 2013. "Bank Characteristics and Stock Reactions to Federal Funds Rate Target Changes." Applied Financial Economics 23 (23): 1755-64. https://doi.org/10.1080/09603107.2013.851770.

Yin, Haiyan, Jiawen Yang, and William C. Handorf. 2010. "State Dependency of Bank Stock Reaction to Federal Funds Rate Target Changes." Journal of Financial Research 33 (3): 289315. https://doi.org/10.1111/j.1475-6803.2010.01272.x. 
Figure-1: Interbank network configurations of two selected European countries

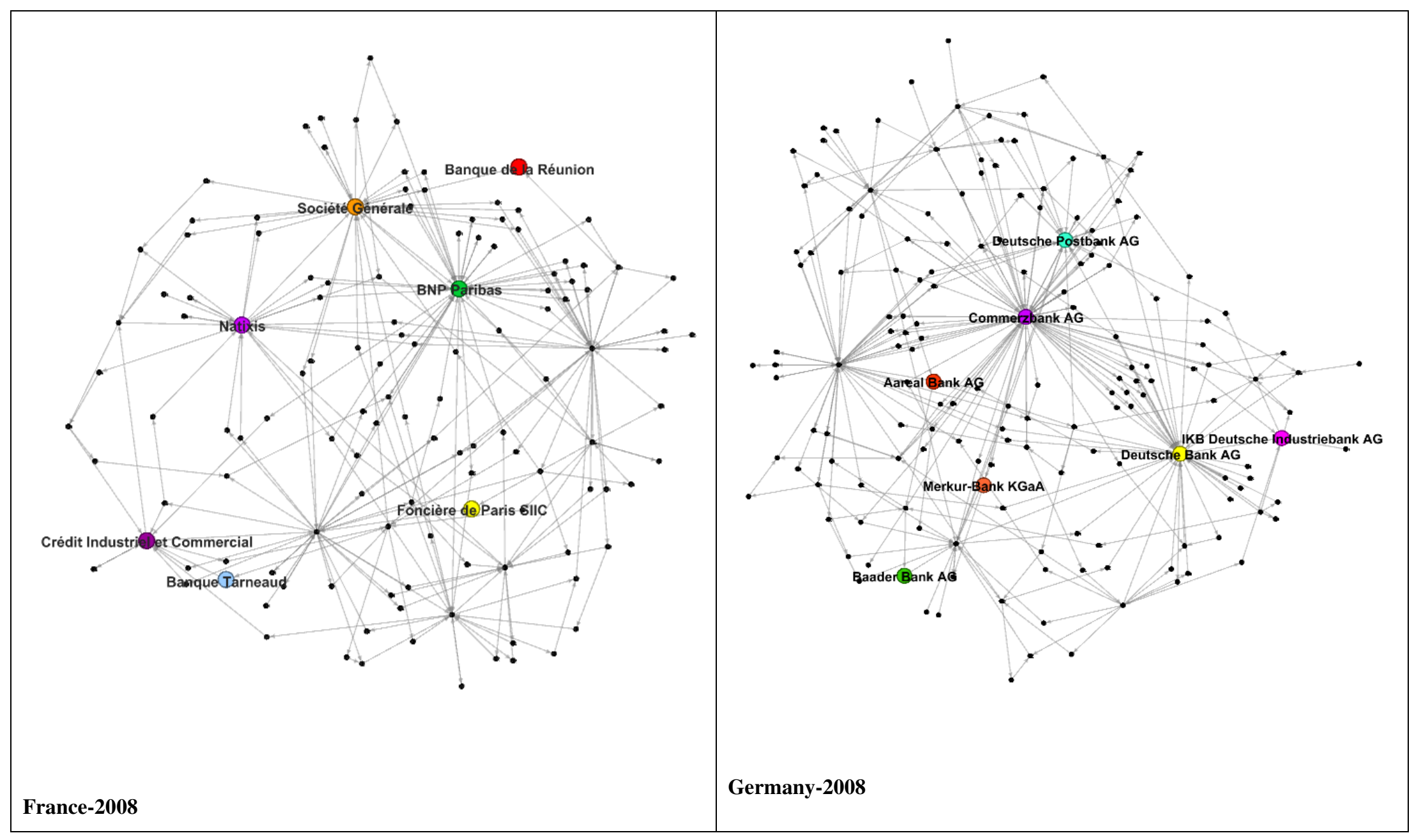


Figure-2: Representation of banks in our sample based on their local (In-Degree) and systemwide interconnectedness (Authority) in 2008

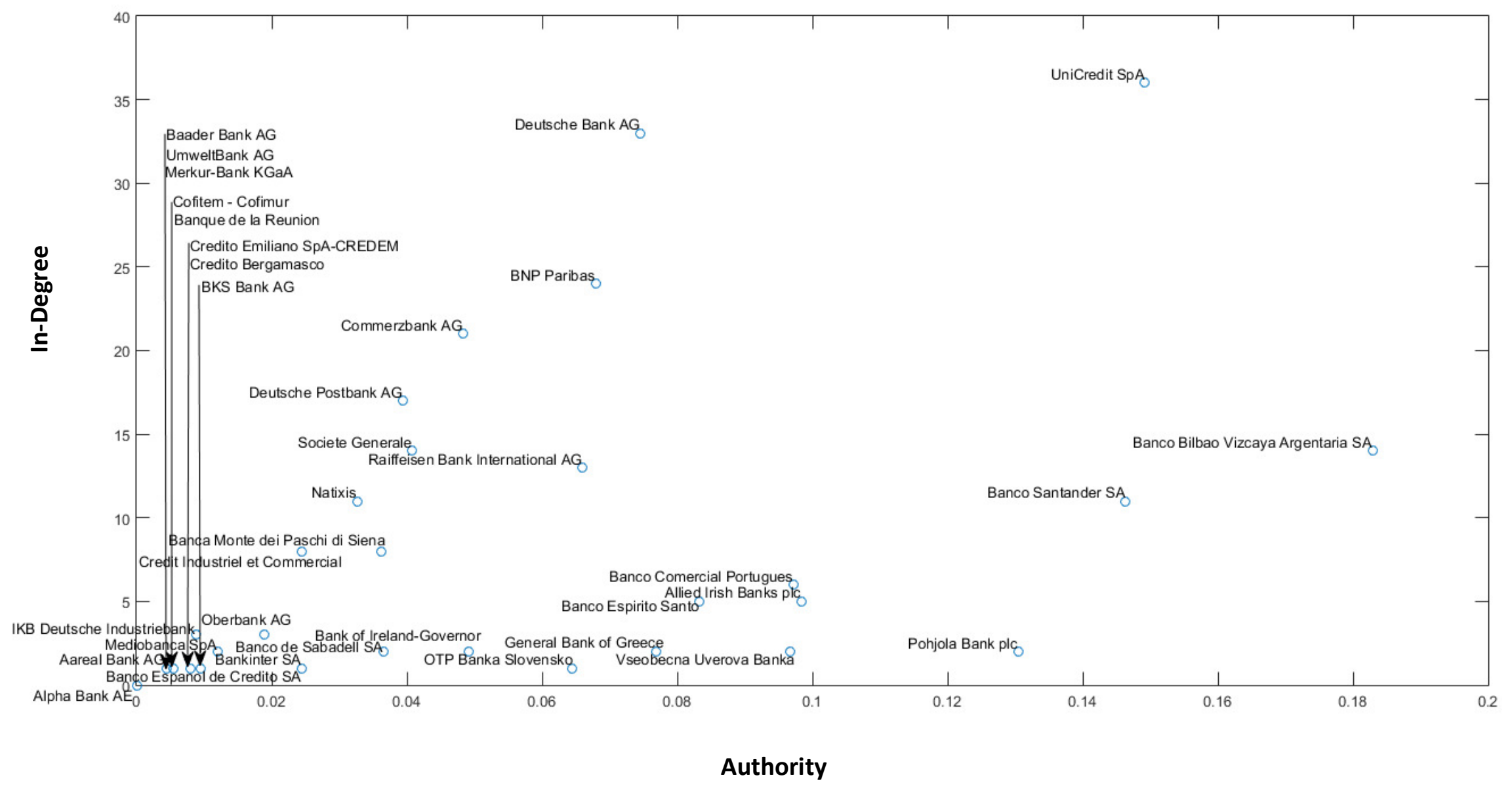


Table-1: Sample of banks

\begin{tabular}{|c|c|}
\hline Bank Name & $\begin{array}{l}\text { Country } \\
\text { Name }\end{array}$ \\
\hline Aareal Bank AG & GERMANY \\
\hline Allied Irish Banks plc & IRELAND \\
\hline Alpha Bank AE & GREECE \\
\hline Attica Bank SA-Bank of Attica SA & GREECE \\
\hline Baader Bank AG & GERMANY \\
\hline Banca Monte dei Paschi di Siena SpA-Gruppo Monte dei Paschi di Siena & ITALY \\
\hline Banco Bilbao Vizcaya Argentaria SA & SPAIN \\
\hline Banco Comercial Portugues, SA-Millennium bcp & PORTUGAL \\
\hline Banco de Sabadell SA & SPAIN \\
\hline Banco Espirito Santo SA & PORTUGAL \\
\hline Banco Santander SA & SPAIN \\
\hline Bank of Ireland-Governor and Company of the Bank of Ireland & IRELAND \\
\hline Bankinter SA & SPAIN \\
\hline Banque de la Reunion SA & FRANCE \\
\hline Banque Tarneaud & FRANCE \\
\hline BKS Bank AG & AUSTRIA \\
\hline BNP Paribas SA & FRANCE \\
\hline Commerzbank AG & GERMANY \\
\hline Credit Industriel et Commercial SA - CIC & FRANCE \\
\hline Credito Emiliano SpA-CREDEM & ITALY \\
\hline Deutsche Bank AG & GERMANY \\
\hline Deutsche Postbank AG & GERMANY \\
\hline Fonciere de Paris SIIC & FRANCE \\
\hline IKB Deutsche Industriebank AG & GERMANY \\
\hline Mediobanca SpA-MEDIOBANCA - Banca di Credito Finanziario Societe per Azioni & ITALY \\
\hline Merkur-Bank KGaA & GERMANY \\
\hline National Bank of Greece SA & GREECE \\
\hline Natixis SA & FRANCE \\
\hline Oberbank AG & AUSTRIA \\
\hline OTP Banka Slovensko, as & SLOVAKIA \\
\hline Pohjola Bank plc-Pohjola Pankki Oyj & FINLAND \\
\hline Raiffeisen Bank International AG & AUSTRIA \\
\hline Societe Generale SA & FRANCE \\
\hline UmweltBank AG & GERMANY \\
\hline UniCredit Bank AG & GERMANY \\
\hline UniCredit SpA & ITALY \\
\hline Vseobecna Uverova Banka a.s. & SLOVAKIA \\
\hline
\end{tabular}


Table-2: Correlation matrix

\begin{tabular}{|c|c|c|c|c|c|c|c|}
\hline & absCAR & lagln-Degree & lagAuthority & lagBank_Size & Size_Dummy & lagROAA & lagNL_DSTF \\
\hline absCAR & 1 & & & & & & \\
\hline lagln-Degree & -0.0577 & 1 & & & & & \\
\hline lagAuthority & 0.0718 & 0.3779 & 1 & & & & \\
\hline lagBank_Size & -0.0182 & 0.6116 & 0.3067 & 1 & & & \\
\hline lagSize_Dummy & -0.0192 & -0.1493 & -0.21 & -0.4279 & 1 & & \\
\hline lagROAA & -0.0122 & -0.0015 & -0.0828 & -0.1558 & 0.1289 & 1 & \\
\hline lagNL_DSTF & -0.0839 & -0.2791 & -0.1365 & -0.1098 & 0.0418 & 0.0459 & 1 \\
\hline lagEq_TA & -0.0267 & -0.2021 & -0.0545 & -0.461 & 0.3519 & 0.456 & 0.0139 \\
\hline laglntrBR & 0.1383 & -0.141 & 0.0174 & -0.0471 & -0.0958 & 0.0915 & -0.0995 \\
\hline lagCost_Inc & 0.0225 & 0.1169 & -0.1268 & 0.2825 & -0.1426 & -0.3893 & -0.2288 \\
\hline lagzscore & -0.0485 & -0.043 & -0.082 & -0.1848 & -0.0824 & 0.222 & -0.1013 \\
\hline ILD & 0.2979 & 0.0813 & -0.2208 & -0.0993 & 0.0261 & 0.139 & -0.1471 \\
\hline Sovereign_Crisis & 0.0242 & -0.0422 & -0.0277 & -0.0037 & -0.0165 & -0.0976 & 0.0113 \\
\hline Global_Crisis & -0.0471 & 0.0265 & -0.0297 & -0.0366 & 0.026 & 0.2911 & -0.0033 \\
\hline & lagEq_TA & lagIntrBR & lagCost_Inc & lagzscore & ILD & Sovereign_Crisis & Global_Crisis \\
\hline
\end{tabular}

\begin{tabular}{|c|c|c|c|c|c|c|c|}
\hline lagEq_TA & 1 & & & & & & \\
\hline lagIntrBR & -0.0192 & 1 & & & & & \\
\hline lagCost_Inc & -0.3971 & 0.0785 & 1 & & & & \\
\hline lagzscore & 0.0433 & -0.1161 & -0.2875 & 1 & & & \\
\hline ILD & -0.0284 & 0.0608 & 0.023 & 0.133 & 1 & & \\
\hline Sovereign_Crisis & 0.0169 & -0.0299 & -0.1034 & -0.087 & -0.0997 & 1 & \\
\hline Global_Crisis & 0.072 & 0.1351 & -0.1036 & 0.0757 & 0.1264 & -0.4283 & 1 \\
\hline
\end{tabular}

This table presents the correlation matrix for network variables and bank level control variables. All dependent and bank-level control variables are winsorized at $1 \%-99 \%$.

Table-3: Descriptive Statistics - Dependent and Independent variables

\begin{tabular}{lrrrrr}
\hline Variables & mean & \multicolumn{1}{l}{ sd } & min & Median & \multicolumn{1}{c}{ Max } \\
\hline absCAR & 0.086 & 0.568 & 0 & 0.01 & 11.009 \\
lagIn-Degree & 7.167 & 9.269 & 0 & 3 & 55 \\
lagAuthority & 0.057 & 0.057 & 0 & 0.036 & 0.429 \\
lagROAA & 0.414 & 1.231 & -6.36 & 0.489 & 4.157 \\
lagNL_DSTF & 92.885 & 32.545 & 5.462 & 88.47 & 201.454 \\
lagEq_TA & 6.959 & 5.648 & 1.449 & 5.997 & 37.125 \\
lagIntrBR & 70.027 & 61.084 & 0.957 & 54.029 & 331.69 \\
lagCost_Inc & 62.164 & 20.906 & 18.047 & 60.068 & 162.202 \\
Lagzscore & 50.199 & 62.192 & 0.749 & 30.293 & 367.456 \\
ILD & 0.095 & 0.042 & 0.022 & 0.088 & 0.301 \\
lagBank_Size & 17.768 & 2.303 & 12.929 & 18.135 & 21.453 \\
Size_Dummy & 0.061 & 0.24 & 0 & 0 & 1 \\
IR_CUT & 0.083 & 0.276 & 0 & 0 & 1 \\
AssetPurchase & 0.097 & 0.296 & 0 & 0 & 1 \\
Sovereign_Crisis & 0.352 & 0.478 & 0 & 0 & 1 \\
Global_Crisis & 0.182 & 0.386 & 0 & 0 & 1 \\
\hline
\end{tabular}


Table-4: Stock market reaction to announcements of 20 unconventional and 52 conventional monetary policies implemented by the ECB for all banks and for banks with extreme value of local or system-wide network interconnectedness.

\begin{tabular}{|c|c|c|c|c|c|c|c|c|c|c|c|c|}
\hline \multirow[b]{2}{*}{$\begin{array}{c}\text { Event } \\
\text { window }\end{array}$} & \multicolumn{4}{|c|}{ Panel A } & \multicolumn{4}{|c|}{ Panel B } & \multicolumn{3}{|c|}{ Panel C } & \\
\hline & $\begin{array}{l}\text { No. } \\
\text { Obs }\end{array}$ & General & & & $\begin{array}{l}\text { No. } \\
\text { Obs }\end{array}$ & $\begin{array}{c}\text { 75th } \\
\text { Percentile }\end{array}$ & & & $\begin{array}{l}\text { No. } \\
\text { Obs }\end{array}$ & $\begin{array}{c}\text { 25th } \\
\text { Percentile }\end{array}$ & & \\
\hline \multicolumn{13}{|c|}{ Asset Purchase Programs (APPs) } \\
\hline & & & & & & In-Degree & & & & In-Degree & & \\
\hline $\mathbf{t}$ & & CAAR & Boehmer & Kolari & & CAAR & Boehmer & Kolari & & CAAR & Boehmer & Kolari \\
\hline$[-1 ; 1]$ & 259 & -0.026124 & & & 69 & 0.0118001 & $* *$ & & 77 & 0.0135588 & & \\
\hline$[0 ; 0]$ & 259 & -0.005252 & & & 69 & 0.0085036 & $* *$ & & 77 & 0.0070696 & & \\
\hline$[0 ; 1]$ & 259 & -0.011973 & & & 69 & 0.0067965 & $* *$ & & 77 & 0.0191542 & & \\
\hline \multirow[t]{2}{*}[-1;3]{} & 259 & -0.045700 & & & 69 & 0.017374 & $* * *$ & $*$ & 77 & 0.0110199 & & \\
\hline & & & & & & Authority & & & & Authority & & \\
\hline $\mathbf{t}$ & & & & & & CAAR & & & & CAAR & & \\
\hline$[-1 ; 1]$ & & & & & 63 & -0.0590541 & & & 70 & 0.0106294 & & \\
\hline$[0 ; 0]$ & & & & & 63 & -0.0606077 & & & 70 & 0.0089117 & & \\
\hline$[0 ; 1]$ & & & & & 63 & -0.0690164 & & & 70 & 0.0131857 & & \\
\hline$[-1 ; 3]$ & & & & & 63 & -0.1202647 & & & 70 & 0.0121174 & & \\
\hline \multicolumn{13}{|c|}{ Liquidity Provision Programs (LPPs) } \\
\hline & & & & & & In-Degree & & & & In-Degree & & \\
\hline $\mathbf{t}$ & & CAAR & Boehmer & Kolari & & CAAR & Boehmer & Kolari & & CAAR & Boehmer & Kolari \\
\hline$[-1 ; 1]$ & 481 & -0.025074 & & & 134 & -0.0022285 & & & 128 & -0.0616081 & & \\
\hline$[0 ; 0]$ & 481 & -0.008134 & & & 134 & 0.0022236 & $* *$ & & 128 & -0.023886 & & \\
\hline$[0 ; 1]$ & 481 & -0.016111 & & & 134 & 0.0024713 & * & & 128 & -0.0428752 & & \\
\hline \multirow[t]{2}{*}[-1;3]{} & 481 & -0.047655 & & & 134 & -0.013385 & & & 128 & -0.1146034 & & \\
\hline & & & & & & Authority & & & & Authority & & \\
\hline $\mathbf{t}$ & & & & & & CAAR & & & & CAAR & & \\
\hline$[-1 ; 1]$ & & & & & 118 & -0.0076544 & & & 113 & 0.0053849 & & \\
\hline$[0 ; 0]$ & & & & & 118 & -0.004301 & $* * *$ & $* * *$ & 113 & 0.0000206 & & \\
\hline$[0 ; 1]$ & & & & & 118 & 0.0028523 & & & 113 & 0.0014354 & & \\
\hline$[-1 ; 3]$ & & & & & 118 & -0.0127861 & & & 113 & -0.0041578 & & \\
\hline \multicolumn{13}{|c|}{ Interest rate-cut (IR_CUT) } \\
\hline & & & & & & In-Degree & & & & In-Degree & & \\
\hline $\mathbf{t}$ & & CAAR & Boehmer & Kolari & & CAAR & Boehmer & Kolari & & CAAR & Boehmer & Kolari \\
\hline$[-1 ; 1]$ & 222 & $-3.31 \mathrm{E}-06$ & & & 60 & 0.0020883 & & & 58 & -0.0126631 & & \\
\hline$[0 ; 0]$ & 222 & 0.0044012 & & & 60 & 0.0029265 & & & 58 & 0.0040402 & & \\
\hline$[0 ; 1]$ & 222 & 0.004983 & & & 60 & 0.0074763 & & & 58 & -0.0005682 & & \\
\hline \multirow[t]{2}{*}[-1;3]{} & 222 & -0.013272 & & & 60 & -0.0088184 & & & 58 & -0.0235705 & & \\
\hline & & & & & & Authority & & & & Authority & & \\
\hline $\mathbf{t}$ & & & & & & CAAR & & & & CAAR & & \\
\hline$[-1 ; 1]$ & & & & & 58 & 0.0075941 & & & 49 & 0.0054169 & & \\
\hline$[0 ; 0]$ & & & & & 58 & -0.0022761 & & & 49 & 0.0000574 & & \\
\hline$[0 ; 1]$ & & & & & 58 & 0.002404 & & & 49 & 0.0029034 & & \\
\hline$[-1 ; 3]$ & & & & & 58 & 0.0068098 & & & 49 & -0.0034539 & & \\
\hline \multicolumn{13}{|c|}{ Increased or unchanged Interest rate (IR_UNC_INC) } \\
\hline & & & & & & In-Degree & & & & In-Degree & & \\
\hline $\mathbf{t}$ & & CAAR & Boehmer & Kolari & & CAAR & Boehmer & Kolari & & CAAR & Boehmer & Kolari \\
\hline$[-1 ; 1]$ & 1702 & -0.036332 & & & 473 & 0.0003532 & & & 497 & -0.0360779 & & \\
\hline$[0 ; 0]$ & 1702 & -0.013703 & & & 473 & 0.0006878 & & & 497 & -0.0136701 & & \\
\hline$[0 ; 1]$ & 1702 & -0.025371 & & & 473 & 0.0001682 & & & 497 & -0.0253451 & & \\
\hline \multirow[t]{2}{*}[-1;3]{} & 1702 & -0.066003 & & & 473 & -0.001831 & & & 497 & -0.0669426 & $* *$ & $* *$ \\
\hline & & & & & & Authority & & & & Authority & & \\
\hline $\mathbf{t}$ & & & & & & CAAR & & & & CAAR & & \\
\hline$[-1 ; 1]$ & & & & & 443 & -0.0924315 & & & 426 & -0.002867 & & \\
\hline$[0 ; 0]$ & & & & & 443 & -0.0340059 & & & 426 & -0.0018293 & & \\
\hline$[0 ; 1]$ & & & & & 443 & -0.0626681 & & & 426 & -0.0022361 & & \\
\hline$[-1 ; 3]$ & & & & & 443 & -0.160006 & & & 426 & -0.0074204 & $* *$ & \\
\hline
\end{tabular}


Table-5: Impact of interbank network variables on the absolute value of CARs during announcements of expansionary and restrictive monetary policies

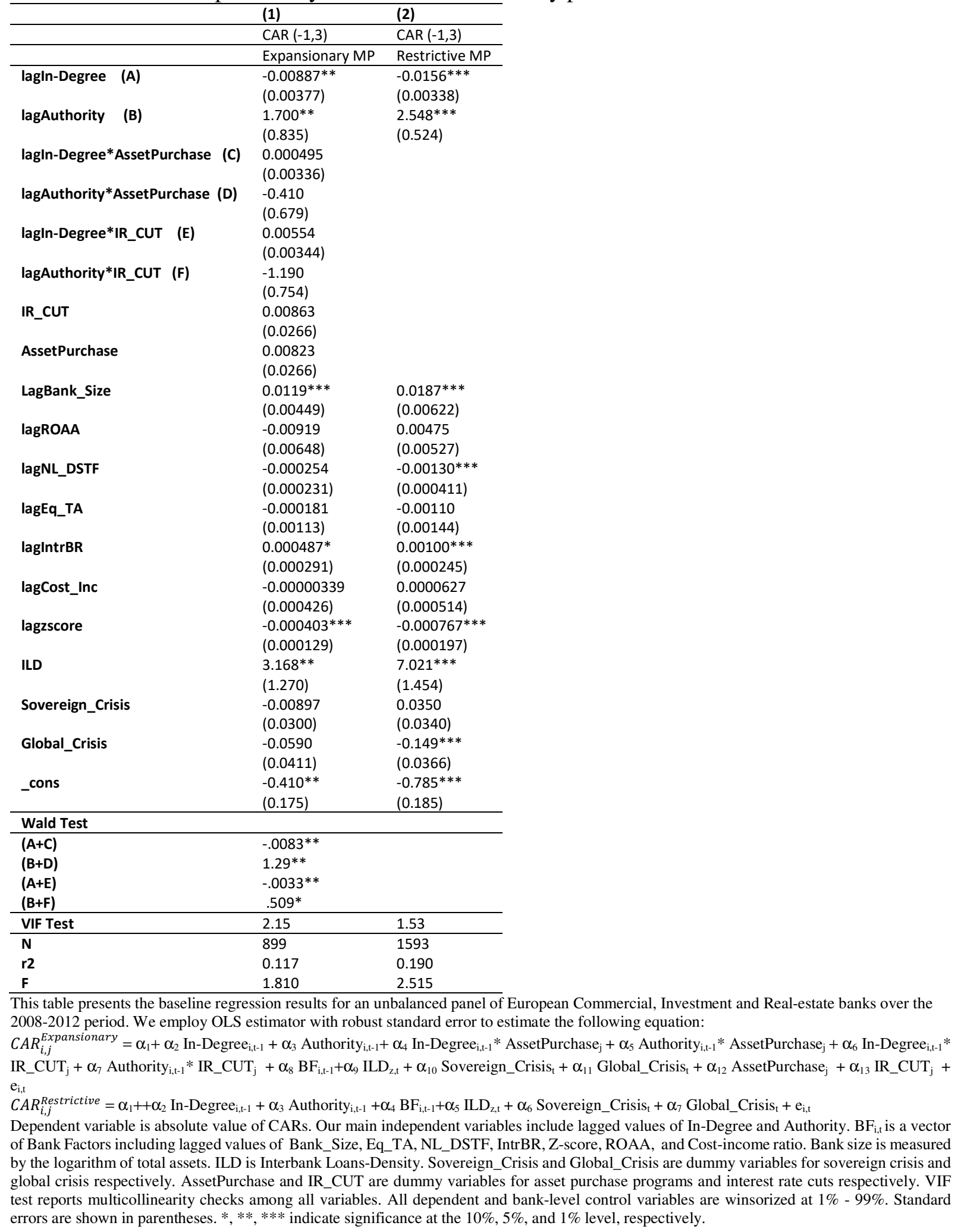


Table-6: Impact of system-wide network position on the absolute value of CARs during announcements of expansionary and restrictive monetary policies: Banks with strong vs weak local interconnectedness

\begin{tabular}{|c|c|c|}
\hline & (1) & $(2)$ \\
\hline & $\operatorname{CAR}(-1,3)$ & $\operatorname{CAR}(-1,3)$ \\
\hline & Expansionary MP & Restrictive MP \\
\hline \multirow[t]{2}{*}{ lagIn-Degree75 } & -0.00670 & $-0.0688^{* *}$ \\
\hline & $(0.0260)$ & $(0.0343)$ \\
\hline \multirow[t]{2}{*}{ lagAuthority (A) } & $1.923^{* *}$ & $2.701^{* * *}$ \\
\hline & $(0.977)$ & $(0.573)$ \\
\hline \multirow[t]{2}{*}{ lagAuthority*AssetPurchase (B) } & -0.513 & \\
\hline & $(0.815)$ & \\
\hline \multirow[t]{2}{*}{ lagAuthority*IR_CUT (C) } & -1.351 & \\
\hline & $(0.905)$ & \\
\hline \multirow{2}{*}{ lagAuthority*lagIn-Degree75 (D) } & $-1.779 *$ & $-1.926 * * *$ \\
\hline & $(0.923)$ & $(0.484)$ \\
\hline \multirow{2}{*}{ lagAuthority*lagIn-Degree75*AssetPurchase (E) } & 0.392 & \\
\hline & $(0.837)$ & \\
\hline \multirow[t]{2}{*}{ lagAuthority*lagIn-Degree75*IR_CUT (F) } & 1.385 & \\
\hline & $(0.938)$ & \\
\hline \multicolumn{3}{|l|}{ Wald Test } \\
\hline$(A+B)$ & $1.409 * *$ & \\
\hline$(A+C)$ & $.572 * *$ & \\
\hline$(A+D)$ & .144 & $.775^{* * *}$ \\
\hline$(A+B+D+E)$ & .0221 & \\
\hline$(A+C+D+F)$ & .1785 & \\
\hline VIF Test & 2.47 & 1.99 \\
\hline $\mathbf{N}$ & 899 & 1593 \\
\hline r2 & 0.116 & 0.182 \\
\hline $\mathbf{F}$ & 1.702 & 2.268 \\
\hline
\end{tabular}

This table presents the regression results for an unbalanced panel of European Commercial, Investment and Real-estate banks over the 20082012 period. We employ OLS estimator with robust standard error to estimate the following equation:

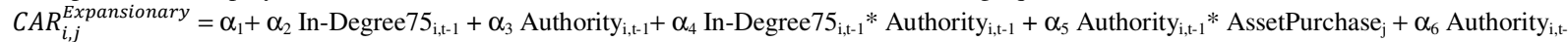

${ }_{1}^{*}$ IR_CUT $_{\mathrm{j}}+\alpha_{7}$ In-Degree75 $5_{\mathrm{i}, \mathrm{t}-\mathrm{1}} *$ Authority $_{\mathrm{i}, \mathrm{t}-} *$ AssetPurchase $_{\mathrm{j}}+\alpha_{8}{ }_{4}$ In-Degree75 $5_{\mathrm{i}, \mathrm{t}-1} *$ Authority $_{\mathrm{i}, \mathrm{t}-} * \mathrm{IR}_{-} \mathrm{CUT}_{\mathrm{i}}+\alpha_{9} \mathrm{BF}_{\mathrm{i}, \mathrm{t}-\mathrm{1}}+\alpha_{9} \mathrm{ILD}_{\mathrm{z}, \mathrm{t}}+\alpha_{10}$ Sovereign_Crisis $+\alpha_{11}$ Global_Crisis $_{\mathrm{t}}+\alpha_{12}$ AssetPurchase $_{\mathrm{j}}+\alpha_{13}$ IR_CUT $_{\mathrm{j}}+\mathrm{e}_{\mathrm{i}, \mathrm{t}}$

CAR Restrictive $_{i, j}=\alpha_{1}+\alpha_{2}$ In-Degree75 $5_{\mathrm{i}, \mathrm{t}-1}+\alpha_{3}$ Authority $_{\mathrm{i}, \mathrm{t}-1}+\alpha_{4}$ In-Degree75 $5_{\mathrm{i}, \mathrm{t}-\mathrm{t}} *$ Authority $_{\mathrm{i}, \mathrm{t}-1}+\alpha_{5} \mathrm{BF}_{\mathrm{i}, \mathrm{t}-1}+\alpha_{6} \mathrm{ILD}_{\mathrm{z}, \mathrm{t}}+\alpha_{7}$ Sovereign $_{-}$Crisis $_{\mathrm{t}}+\alpha_{8}$ Global_Crisis ${ }_{\mathrm{t}}+\mathrm{e}_{\mathrm{i}, \mathrm{t}}$

Dependent variable is absolute value of CARs. Our main independent variables include lagged value of Authority. $\mathrm{BF}_{\mathrm{i}, \mathrm{t}}$ is a vector of Bank Factors including lagged values of Bank Size, Eq_TA, NL_DSTF, IntrBR, Z-score, ROAA, and Cost-income ratio. Bank size is measured by the logarithm of total assets. ILD is Interbank Loans-Density. Sovereign_Crisis and Global_Crisis are dummy variables for sovereign crisis and global crisis respectively. AssetPurchase and IR_CUT are dummy variables for asset purchase programs and interest rate cuts respectively. In-Degree75 is a dummy variable that takes the value of one if In-Degree is greater than or equal to the 75th percentile value. VIF test reports multicollinearity checks among all variables. All dependent and bank-level control variables are winsorized at $1 \%-99 \%$. Standard errors are shown in parentheses. $*, * *, * * *$ indicate significance at the $10 \%, 5 \%$, and $1 \%$ level, respectively. 


\section{Appendix}

Table-A1: The Variance Inflation Factor (VIF) test for multicollinearity

\begin{tabular}{lrl}
\hline \multicolumn{1}{c}{ Variable } & VIF & \multicolumn{1}{l}{$\mathbf{1 / V I F}$} \\
\hline lagBank_Size & 2.2 & 0.455231 \\
lagIn-Degree & 2.02 & 0.494357 \\
lagAuthority & 1.44 & 0.692544 \\
lagEq_TA & 1.78 & 0.560287 \\
lagCost_Inc & 1.67 & 0.600468 \\
lagROAA & 1.64 & 0.609907 \\
Global_Crisis & 1.38 & 0.722477 \\
Sovereign_Crisis & 1.32 & 0.758945 \\
lagzscore & 1.29 & 0.776987 \\
lagNL_DSTF & 1.28 & 0.782919 \\
CountryLAATB_CountryTA & 1.21 & 0.829435 \\
lagIntrBR & 1.13 & 0.883896 \\
& & \\
\hline Mean VIF & 1.53 & \\
\hline VIF test results for Equation 6 & &
\end{tabular}

VIF test results for Equation 6

Table-A2: Impact of interbank network variables on the absolute value of CARs belonging to 1day, 2-day and 3-day event windows during the announcements of expansionary monetary policies

\begin{tabular}{|c|c|c|c|}
\hline & (1) & (2) & (3) \\
\hline & $\operatorname{CAR}(-1,1)$ & $\operatorname{CAR}(0,0)$ & $\operatorname{CAR}(0,1)$ \\
\hline \multirow[t]{2}{*}{ lagln-Degree (A) } & $-0.00523 * *$ & $-0.00215^{* *}$ & $-0.00359 * *$ \\
\hline & $(0.00212)$ & $(0.000921)$ & $(0.00151)$ \\
\hline \multirow[t]{2}{*}{ lagAuthority (B) } & $0.977 * *$ & $0.375^{* *}$ & $0.603 *$ \\
\hline & $(0.467)$ & $(0.183)$ & $(0.318)$ \\
\hline \multirow[t]{2}{*}{ lagln-Degree*AssetPurchase (C) } & 0.00111 & -0.000777 & -0.000631 \\
\hline & $(0.00191)$ & $(0.00154)$ & $(0.00188)$ \\
\hline \multirow[t]{2}{*}{ lagAuthority*AssetPurchase (D) } & -0.334 & 0.0675 & -0.0552 \\
\hline & $(0.391)$ & $(0.249)$ & $(0.327)$ \\
\hline \multirow[t]{2}{*}{ lagIn-Degree*IR_CUT (E) } & $0.00369 *$ & 0.000813 & 0.00191 \\
\hline & $(0.00203)$ & $(0.000865)$ & $(0.00136)$ \\
\hline \multirow[t]{2}{*}{ lagAuthority*IR_CUT (F) } & -0.610 & -0.181 & -0.380 \\
\hline & $(0.439)$ & $(0.196)$ & $(0.305)$ \\
\hline \multicolumn{4}{|l|}{ Wald Test } \\
\hline$(A+C)$ & $-.004 * *$ & -.0029 & $-.0042^{*}$ \\
\hline$(B+D)$ & $.643 * *$ & $.442 *$ & $.547^{*}$ \\
\hline$(A+E)$ & -.001 & $-.0013 *$ & $-.0016 * *$ \\
\hline$(B+F)$ & $.367^{*}$ & .194 & .222 \\
\hline $\mathbf{N}$ & 899 & 899 & 899 \\
\hline r2 & 0.116 & 0.0785 & 0.0913 \\
\hline $\mathbf{F}$ & 2.042 & 2.012 & 1.839 \\
\hline
\end{tabular}

This table presents the regression results for an unbalanced panel of European Commercial, Investment and Real-estate banks over the 20082012 period. We employ OLS estimator with robust standard error to estimate the following equation:

CAR $_{i, j}^{\text {Expansionary }}=\alpha_{1}+\alpha_{2}$ In-Degree $_{\mathrm{i}, \mathrm{t}-1}+\alpha_{3}$ Authority $_{\mathrm{i}, \mathrm{t}-1}+\alpha_{4}$ In-Degree $_{\mathrm{i}, \mathrm{t}-\mathrm{1}} *$ AssetPurchase $_{\mathrm{j}}+\alpha_{5}$ Authority $_{\mathrm{i}, \mathrm{t}-1} *$ AssetPurchase $_{\mathrm{j}}+\alpha_{6}$ In-Degree $_{\mathrm{i}, \mathrm{t}-1} *$

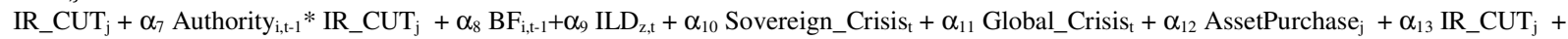
$\mathrm{e}_{\mathrm{i}, \mathrm{t}}$

Dependent variable is absolute value of CARs. Our main independent variables include lagged values of In-Degree and Authority. BF $\mathrm{i}_{\mathrm{i}, \mathrm{t}}$ is a vector of Bank Factors including lagged values of Bank Size, Eq_TA, NL_DSTF, IntrBR, Z-score, ROAA, and Cost-income ratio. Bank size is measured by the logarithm of total assets. ILD is Interbank Loans-Density. Sovereign_Crisis and Global_Crisis are dummy variables for sovereign crisis and global crisis respectively. AssetPurchase and IR_CUT are dummy variables for asset purchase programs and interest rate cuts respectively. All dependent and bank-level control variables are winsorized at $1 \%-99 \%$. Standard errors are shown in parentheses. *,**,*** indicate significance at the $10 \%, 5 \%$, and $1 \%$ level, respectively. 
Table-A3: Impact of interbank network variables on the absolute value of CARs belonging to 1day, 2-day and 3-day event windows during the announcements of restrictive monetary policy

\begin{tabular}{llll}
\hline & $\mathbf{( 1 )}$ & $\mathbf{( 2 )}$ & $\mathbf{( 3 )}$ \\
\hline & $\operatorname{CAR}(-1,1)$ & $\operatorname{CAR}(0,0)$ & CAR $(0,1)$ \\
\hline lagIn-Degree & $-0.00914^{* * *}$ & $-0.00317^{* * *}$ & $-0.00603^{* * *}$ \\
& $(0.00206)$ & $(0.000765)$ & $(0.00142)$ \\
lagAuthority & $1.487^{* * *}$ & $0.525^{* * *}$ & $0.993^{* * *}$ \\
& $(0.314)$ & $(0.114)$ & $(0.212)$ \\
& & & \\
\hline $\mathbf{N}$ & 1593 & 1593 & 1593 \\
r2 & 0.177 & 0.164 & 0.169 \\
$\mathbf{F}$ & 2.715 & 3.608 & 2.968 \\
\hline
\end{tabular}

This table presents the regression results for an unbalanced panel of European Commercial, Investment and Real-estate banks over the 20082012 period. We employ OLS estimator with robust standard error to estimate the following equation:

$C A R_{i, j}^{\text {Restrictive }}=\alpha_{1}++\alpha_{2}$ In-Degree $_{\mathrm{i}, \mathrm{t}-1}+\alpha_{3}$ Authority $_{\mathrm{i}, \mathrm{t}-1}+\alpha_{4} \mathrm{BF}_{\mathrm{i}, \mathrm{t}-1}+\alpha_{5} \mathrm{ILD}_{\mathrm{z}, \mathrm{t}}+\alpha_{6}$ Sovereign_Crisis $_{\mathrm{t}}+\alpha_{7}$ Global_Crisis $_{\mathrm{t}}+\mathrm{e}_{\mathrm{i}, \mathrm{t}}$

Dependent variable is absolute value of CARs. Our main independent variables are lagged values of In-Degree and Authority. $\mathrm{BF}_{\mathrm{i}, \mathrm{t}}$ is a vector of Bank Factors including lagged values of Bank Size, Eq_TA, NL_DSTF, IntrBR, Z-score, ROAA, and Cost-income ratio. Bank Size is measured by the logarithm of total assets. ILD is Interbank Loans-Density. Sovereign_Crisis and Global_Crisis are dummy variables for sovereign crisis and global crisis respectively. All dependent and bank-level control variables are winsorized at 1\% - 99\%. Standard errors are shown in parentheses. *, $* *, * * *$ indicate significance at the $10 \%, 5 \%$, and $1 \%$ level, respectively.

Table-A4: Impact of interbank network variables on the absolute value of CARs using alternative measures of network variables

\begin{tabular}{lll}
\hline & $\mathbf{( 1 )}$ & $\mathbf{( 2 )}$ \\
\hline & CAR (-1,3) & CAR (-1,3) \\
\hline lagDegree (A) & Expansionary MP & Restrictive MP \\
\hline & $-0.00544^{* *}$ & $-0.00981^{* * *}$ \\
lagCloseness (B) & $(0.00211)$ & $(0.00208)$ \\
& $0.616^{*}$ & $1.208^{* * *}$ \\
lagDegree*AssetPurchase (C) & $(0.331)$ & $(0.252)$ \\
& -0.000834 & \\
lagCloseness*AssetPurchase (D) & $(0.00206)$ & \\
& -0.00434 & \\
lagDegree*IR_CUT (E) & $(0.412)$ & \\
& $0.00333^{*}$ & \\
lagCloseness*IR_CUT (F) & $(0.00189)$ & \\
& $-0.697^{*}$ & \\
\hline Wald Test & $(0.357)$ & \\
\hline (A+C) & & \\
(B+D) & $-.0062^{* *}$ & \\
(A+E) & $.6114^{*}$ & \\
(B+F) & $-.0021^{* *}$ & 0.210 \\
\hline $\mathbf{N}$ & -.0817 & 2.477 \\
r2 & 899 & \\
F & 0.125 & \\
\hline
\end{tabular}

This table presents the regression results for an unbalanced panel of European Commercial, Investment and Real-estate banks over the 20082012 period. We employ OLS estimator with robust standard error to estimate the following equations:

CAR $_{i, j}^{\text {Expansionary }}=\alpha_{1}+\alpha_{2}$ Degree $_{\mathrm{i}, \mathrm{t}-1}+\alpha_{3}$ Closeness $_{\mathrm{i}, \mathrm{t}-1}+\alpha_{4}$ Degree $_{\mathrm{i}, \mathrm{t}-\mathrm{*}} *$ AssetPurchase $_{\mathrm{j}}+\alpha_{5}$ Closeness $_{\mathrm{i}, \mathrm{t}-1} *$ AssetPurchase $_{\mathrm{j}}+\alpha_{6}$ Degree $_{\mathrm{i}, \mathrm{t}-1} * \mathrm{IR}_{-}$CUT $_{\mathrm{j}}$ $+\alpha_{7}$ Closeness $_{\mathrm{i}, \mathrm{t}-1} *$ IR_CUT $_{\mathrm{j}}+\alpha_{8}$ BF $_{\mathrm{i}, \mathrm{t}-1}+\alpha_{9}$ ILD $_{\mathrm{z}, \mathrm{t}}+\alpha_{10}$ Sovereign_Crisis $_{\mathrm{t}}+\alpha_{11}$ Global_Crisis $_{\mathrm{t}}+\alpha_{12}$ AssetPurchase $_{\mathrm{j}}+\alpha_{13}$ IR_CUT $_{\mathrm{j}}+\mathrm{e}_{\mathrm{i}, \mathrm{t}}$

$C A R_{i, j}^{\text {Restrictive }}=\alpha_{1}++\alpha_{2}$ Degree $_{\mathrm{i}, \mathrm{t}-1}+\alpha_{3}$ Closeness $_{\mathrm{i}, \mathrm{t}-1}+\alpha_{4} \mathrm{BF}_{\mathrm{i}, \mathrm{t}-1}+\alpha_{5} \operatorname{ILD}_{\mathrm{z}, \mathrm{t}}+\alpha_{6}$ Sovereign_Crisis $_{\mathrm{t}}+\alpha_{7}$ Global_Crisis $_{\mathrm{t}}+\mathrm{e}_{\mathrm{i}, \mathrm{t}}$

Dependent variable is absolute value of CARs. Our main independent variables include lagged values of Degree and Closeness. $\mathrm{BF}_{\mathrm{i}, \mathrm{t}}$ is a vector of Bank Factors including lagged values of Bank Size, Eq_TA, NL_DSTF, IntrBR, Z-score, ROAA, and Cost-income ratio. Bank Size is measured by the logarithm of total assets. ILD is Interbank Loans-Density. Sovereign_Crisis and Global_Crisis are dummy variables for sovereign crisis and global crisis respectively. AssetPurchase and IR_CUT are dummy variables for asset purchase programs and interest rate cuts respectively. All dependent and bank-level control variables are winsorized at $1 \%-99 \%$. Standard errors are shown in parentheses. *, **, *** indicate significance at the $10 \%, 5 \%$, and $1 \%$ level, respectively. 
Table-A5: Impact of interbank network variables on the absolute value of CARs: Size dummy and Orthogonalizing Bank size and In-Degree

\begin{tabular}{|c|c|c|c|c|}
\hline & (1) & (2) & (3) & (4) \\
\hline & $\operatorname{CAR}(-1,3)$ & $\operatorname{CAR}(-1,3)$ & $\operatorname{CAR}(-1,3)$ & $\operatorname{CAR}(-1,3)$ \\
\hline & Expansionary MP & Restrictive MP & Expansionary MP & Restrictive MP \\
\hline \multirow[t]{2}{*}{ lagln-Degree (A) } & $-0.00731^{* *}$ & $-0.0134 * * *$ & $-0.00705^{* *}$ & $-0.0127^{* * *}$ \\
\hline & (0.00339) & $(0.00281)$ & $(0.00333)$ & $(0.00266)$ \\
\hline \multirow[t]{2}{*}{ lagAuthority (B) } & $1.742 * *$ & $2.640 * * *$ & $1.699 * *$ & $2.547 * * *$ \\
\hline & $(0.851)$ & $(0.540)$ & $(0.835)$ & $(0.524)$ \\
\hline \multirow[t]{2}{*}{ lagIn-Degree*AssetPurchase (C) } & 0.000349 & & 0.000496 & \\
\hline & $(0.00337)$ & & $(0.00336)$ & \\
\hline \multirow[t]{2}{*}{ lagAuthority*AssetPurchase (D) } & -0.423 & & -0.410 & \\
\hline & $(0.680)$ & & $(0.679)$ & \\
\hline \multirow[t]{2}{*}{ lagIn-Degree*IR_CUT (E) } & 0.00550 & & 0.00554 & \\
\hline & $(0.00345)$ & & $(0.00344)$ & \\
\hline \multirow[t]{2}{*}{ lagAuthority*IR_CUT (F) } & -1.167 & & -1.190 & \\
\hline & $(0.750)$ & & $(0.754)$ & \\
\hline \multirow[t]{2}{*}{ IR_CUT } & 0.00706 & & 0.00864 & \\
\hline & $(0.0268)$ & & $(0.0266)$ & \\
\hline \multirow[t]{2}{*}{ AssetPurchase } & 0.00920 & & 0.00822 & \\
\hline & $(0.0265)$ & & $(0.0266)$ & \\
\hline \multirow{2}{*}{ lagSize_Dummy } & 0.00475 & 0.0266 & & \\
\hline & $(0.0197)$ & $(0.0265)$ & & \\
\hline \multirow[t]{2}{*}{ lagOr_LNTA } & & & $0.0218^{* * *}$ & $0.0344 * * *$ \\
\hline & & & $(0.00823)$ & $(0.0114)$ \\
\hline \multicolumn{5}{|l|}{ Wald Test } \\
\hline$(A+C)$ & $-.0069 * * *$ & & $-.0069 * * *$ & \\
\hline$(B+D)$ & $1.318^{* * *}$ & & $1.318^{* * *}$ & \\
\hline$(A+E)$ & -.0018 & & -.0018 & \\
\hline$(B+F)$ & $.574 * *$ & & $.574 * *$ & \\
\hline $\mathbf{N}$ & 899 & 1593 & 899 & 1593 \\
\hline r2 & 0.115 & 0.189 & 0.115 & 0.189 \\
\hline $\mathbf{F}$ & 1.738 & 2.590 & 1.738 & 2.590 \\
\hline
\end{tabular}

This table presents the regression results for an unbalanced panel of European Commercial, Investment and Real-estate banks over the 20082012 period. We employ OLS estimator with robust standard error to estimate the following equation:

CAR $_{i, j}^{\text {Expansionary }}=\alpha_{1}+\alpha_{2}$ In-Degree $_{\mathrm{i}, \mathrm{t}-1}+\alpha_{3}$ Authority $_{\mathrm{i}, \mathrm{t}-1}+\alpha_{4}$ In-Degree $_{\mathrm{i}, \mathrm{t}-\mathrm{1}} *$ AssetPurchase $_{\mathrm{j}}+\alpha_{5}$ Authority $_{\mathrm{i}, \mathrm{t}-1} *$ AssetPurchase $_{\mathrm{j}}+\alpha_{6}$ In-Degree $_{\mathrm{i}, \mathrm{t}-\mathrm{1}} *$ $\mathrm{IR}_{-} \mathrm{CUT}_{\mathrm{j}}+\alpha_{7}$ Authority $_{\mathrm{i}, \mathrm{t}-1} * \mathrm{IR}_{-} \mathrm{CUT}_{\mathrm{j}}+\alpha_{8} \mathrm{BF}_{\mathrm{i}, \mathrm{t}-1}+\alpha_{9} \mathrm{ILD}_{\mathrm{z}, \mathrm{t}}+\alpha_{10}$ Sovereign_Crisis $_{\mathrm{t}}+\alpha_{11}$ Global_Crisis $_{\mathrm{t}}+\alpha_{12}$ AssetPurchase $_{\mathrm{j}}+\alpha_{13} \mathrm{IR}_{-} \mathrm{CUT}_{\mathrm{j}}+$ $\mathrm{e}_{\mathrm{i}, \mathrm{t}}$

Dependent variable is absolute value of CARs. Our main independent variables include lagged value of In-Degree and Authority. $\mathrm{BF}_{\mathrm{i}, \mathrm{t}}$ is a vector of Bank Factors including lagged values of Size, Eq_TA, NL_DSTF, IntrBR, Z-score, ROAA, and Cost-income ratio. Size is measured by the lagged values of the Orthogonal vector of bank size (columns 3 to 4 ) and size dummy (columns 1 to 2 ). Size dummy takes the value of one for small banks (banks with total assets less than one billion Euro) and zero otherwise. ILD is Interbank Loans-Density. Sovereign_Crisis and Global_Crisis are dummy variables for sovereign crisis and global crisis respectively. AssetPurchase and IR_CUT are dummy variables for asset purchase programs and interest rate cuts respectively. All dependent and bank-level control variables are winsorized at $1 \%$ - $99 \%$. Standard errors are shown in parentheses. $*$, **, *** indicate significance at the $10 \%, 5 \%$, and $1 \%$ level, respectively. 
Table-A6: Impact of interbank network variables on the absolute value of CARs using an alternative definition of high borrowing structure diversification (In-Degree50)

\begin{tabular}{|c|c|c|}
\hline & (1) & $(2)$ \\
\hline & $\operatorname{CAR}(-1,3)$ & $\operatorname{CAR}(-1,3)$ \\
\hline & Expansionary MP & Restrictive MP \\
\hline \multirow[t]{2}{*}{ lagInDegree50 } & $-0.0871 * * *$ & $-0.178 * * *$ \\
\hline & $(0.0286)$ & $(0.0444)$ \\
\hline \multirow[t]{2}{*}{ lagAuthority (A) } & $2.334 * *$ & $4.933 * * *$ \\
\hline & $(1.083)$ & $(1.054)$ \\
\hline \multirow[t]{2}{*}{ lagAuthority*AssetPurchase (B) } & 0.391 & \\
\hline & $(0.633)$ & \\
\hline \multirow[t]{2}{*}{ lagAuthority*IR_CUT (C) } & -0.503 & \\
\hline & $(0.584)$ & \\
\hline \multirow[t]{2}{*}{ lagAuthority*lagInDegree50 (D) } & $-1.376^{* *}$ & $-3.247 * * *$ \\
\hline & $(0.673)$ & $(0.794)$ \\
\hline \multirow[t]{2}{*}{ lagAuthority*lagInDegree50*AssetPurchase (E) } & $-0.0478 *$ & \\
\hline & $(0.0276)$ & \\
\hline \multirow[t]{2}{*}{ lagAuthority*lagInDegree50*IR_CUT (F) } & -0.00174 & \\
\hline & $(0.0165)$ & \\
\hline \multicolumn{3}{|l|}{ Wald Test } \\
\hline$(A+B)$ & $2.725 * * *$ & \\
\hline$(A+C)$ & $1.831 * *$ & \\
\hline$(A+D)$ & $.9578 * *$ & $1.686 * * *$ \\
\hline$(A+B+D+E)$ & $1.301 * *$ & \\
\hline$(A+C+D+F)$ & .4533 & \\
\hline $\mathbf{N}$ & 899 & 1593 \\
\hline$r 2$ & 0.131 & 0.211 \\
\hline $\mathbf{F}$ & 1.918 & 2.499 \\
\hline
\end{tabular}

This table presents the regression results for an unbalanced panel of European Commercial, Investment and Real-estate banks over the 20082012 period. We employ OLS estimator with robust standard error to estimate the following equation:

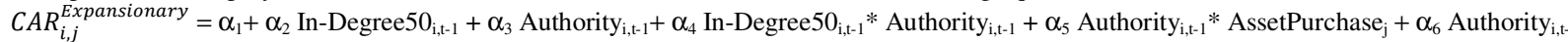
$1^{*}$ IR_CUT $_{\mathrm{j}}+\alpha_{7}$ In-Degree50 $0_{\mathrm{i}, \mathrm{t}-\mathrm{l}} *$ Authority $_{\mathrm{i}, \mathrm{t}-} *$ AssetPurchase $_{\mathrm{j}}+\alpha_{8}{ }_{4}$ In-Degree50 $0_{\mathrm{i}, \mathrm{t}-1} *$ Authority $_{\mathrm{i}, \mathrm{t}-} * \mathrm{IR}_{-} \mathrm{CUT}_{\mathrm{i}}+\alpha_{9} \mathrm{BF}_{\mathrm{i}, \mathrm{t}-\mathrm{l}}+\alpha_{9} \mathrm{ILD}_{\mathrm{z}, \mathrm{t}}+\alpha_{10}$ Sovereign_Crisis $\mathrm{t}_{\mathrm{t}}+\alpha_{11}$ Global_Crisis $_{\mathrm{t}}+\alpha_{12}$ AssetPurchase $_{\mathrm{j}}+\alpha_{13} \mathrm{IR}_{\mathrm{I}}$ CUT $_{\mathrm{j}}+\mathrm{e}_{\mathrm{i}, \mathrm{t}}$

CAR Restrictive $=\alpha_{1}+\alpha_{2}$ In-Degree50 $0_{\mathrm{i}, \mathrm{t}-1}+\alpha_{3}$ Authority $_{\mathrm{i}, \mathrm{t}-1}+\alpha_{4}$ In-Degree $_{0_{\mathrm{i}, \mathrm{t}-\mathrm{1}}} *$ Authority $_{\mathrm{i}, \mathrm{t}-1}+\alpha_{5} \mathrm{BF}_{\mathrm{i}, \mathrm{t}-1}+\alpha_{6} \mathrm{ILD}_{\mathrm{z}, \mathrm{t}}+\alpha_{7}$ Sovereign_Crisis $_{\mathrm{t}}+\alpha_{8}$ Global_Crisis $\mathrm{t}_{\mathrm{t}}+\mathrm{e}_{\mathrm{i}, \mathrm{t}}$

Dependent variable is absolute value of CARs. Our main independent variable is lagged value of Authority. $\mathrm{BF}_{\mathrm{i}, \mathrm{t}}$ is a vector of Bank Factors including lagged values of Bank Size, Eq_TA, NL_DSTF, IntrBR, Z-score, ROAA, and Cost-income ratio. Bank Size is measured by the logarithm of total assets. ILD is Interbank Loans-Density. Sovereign_Crisis and Global_Crisis are dummy variables for sovereign crisis and global crisis respectively. AssetPurchase and IR CUT are dummy variables for asset purchase programs and interest rate cuts respectively. In-Degree50 is a dummy variable that takes the value of one if In-Degree is greater than or equal to the median value. All dependent and bank-level control variables are winsorized at $1 \%-99 \%$. Standard errors are shown in parentheses. *, **, *** indicate significance at the $10 \%, 5 \%$, and $1 \%$ level, respectively. 